Article

\title{
Geochemical Characterization of Trace MVT Mineralization in Paleozoic Sedimentary Rocks of Northeastern Wisconsin, USA
}

\author{
John A. Luczaj ${ }^{1, *}$, Michael J. McIntire ${ }^{2}$ and Megan J. Olson Hunt ${ }^{3}$ \\ 1 Department of Natural \& Applied Sciences (Geoscience), University of Wisconsin-Green Bay, Green Bay, \\ WI 54311, USA \\ 2 Department of Natural \& Applied Sciences (Chemistry), University of Wisconsin-Green Bay, Green Bay, \\ WI 54311, USA; mcintirm@uwgb.edu \\ 3 Department of Natural \& Applied Sciences (Statistics), University of Wisconsin-Green Bay, Green Bay, \\ WI 54311, USA; olsonhum@uwgb.edu \\ * Correspondence: luczajj@uwgb.edu; Tel.: +1-920-465-5139
}

Academic Editor: Michael D. Campbell

Received: 21 March 2016; Accepted: 12 June 2016; Published: 21 June 2016

\begin{abstract}
Disseminated Mississippi Valley-type (MVT) mineralization occurs throughout northeastern Wisconsin, USA, and is recognized as the source of regionally extensive natural groundwater contamination in the form of dissolved arsenic, nickel, and other related metals. Although considerable attention has been given to arsenic contamination of groundwater in the region, limited attention has been focused on characterizing the bedrock sources of these and other metals. A better understanding of the potential sources of groundwater contamination is needed, especially in areas where groundwater is the dominant source of drinking water. This article describes the regional, stratigraphic, and petrographic distribution of MVT mineralization in Paleozoic rocks of northeastern Wisconsin, with a focus on sulfide minerals. Whole-rock geochemical analysis performed on 310 samples of dolomite, sandstone, and shale show detectable levels of arsenic, nickel, cobalt, copper, lead, zinc, and other metals related to various sulfide mineral phases identified using scanning electron microscopy. MVT minerals include pyrite, marcasite, sphalerite, galena, chalcopyrite, fluorite, celestine, barite, and others. We describe the first nickel- and cobalt-bearing sulfide mineral phases known from Paleozoic strata in the region. Arsenic, nickel, and cobalt are sometimes present as isomorphous substitutions in pyrite and marcasite, but discrete mineral phases containing nickel and cobalt elements are also observed, including bravoite and vaesite. Locally abundant stratigraphic zones of sulfide minerals occur across the region, especially in the highly enriched Sulfide Cement Horizon at the top of the Ordovician St. Peter Sandstone. Abundant quantities of sulfides also appear near the contact between the Silurian Mayville Formation and the underlying Maquoketa and Neda formations in certain areas along and east of the Niagara escarpment. This article illustrates how a detailed geochemical and mineralogical investigation can yield a better understanding of groundwater quality problems.
\end{abstract}

Keywords: Wisconsin; Paleozoic; vaesite; bravoite; sulfide; nickel; cobalt; arsenic

\section{Introduction}

Mississippi Valley-Type (MVT) lead-zinc ore deposits are carbonate-hosted accumulations of sulfide and associate minerals that are dominated by sphalerite, galena, iron sulfides, and other associated minerals. They typically occur in Phanerozoic dolostone (with some in limestone or sandstone) located on the flanks of sedimentary basins, orogenic forelands, or foreland thrust belts [1-3]. MVT ore deposits are located throughout the world, but were named for deposits that occur along the 
Mississippi River Valley in North America. Large, well-studied deposits occur in the United States and Canada [1-5], Europe (especially Ireland and Poland) [3,5-7], and elsewhere. Modern interpretations of the origin of MVT ore deposits generally include large-scale brine migration driven within platform carbonates by large-scale tectonic events [3].

The upper Mississippi Valley region of southwest Wisconsin, eastern Iowa, and northwestern Illinois, USA (Figure 1) contains a historic Mississippi Valley-type (MVT) ore district [8]. Although the lead mineralization in the region was discovered during the late 17th century, these deposits did not receive major attention until the early 19th century. It was in this region that the first large "metals rush" in the United States took place in what is known as the Upper Mississippi Valley Zinc-Lead Ore District. Galena, and later sphalerite, were the two principal minerals of interest in small ore bodies located near folds and faults hosted by Paleozoic carbonate rocks [8]. The likelihood of a hydrothermal origin for these deposits was recognized by the mid-20th century by Heyl et al. and McLimans [8,9]. Research by Sverjensky, Garven, Bethke, Rowan and others during the 1980s and 1990s led to the general acceptance that these deposits were the result of northward basin-scale brine migration from the Illinois basin $[1,2,10,11]$. The economic viability of these deposits faded during the later 20th century, and the last mine in the district closed in 1979.

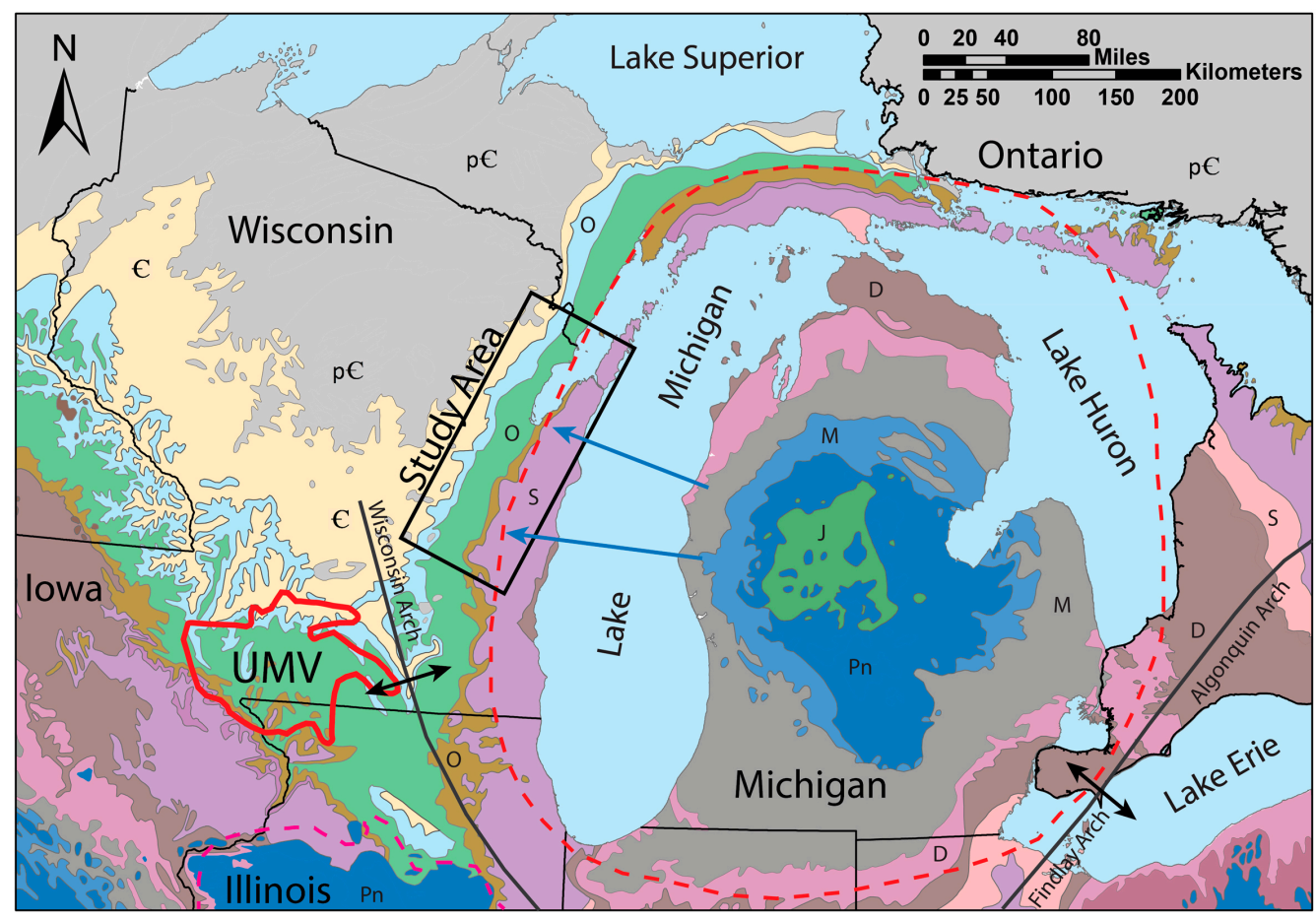

Figure 1. Bedrock geologic map of the western Great Lakes region of North America showing the locations of major geologic structures near the states of Wisconsin and Michigan. Geologic rock systems are as follows: $\mathrm{p} E=$ Precambrian, $\mathrm{E}=$ Cambrian, $\mathrm{O}=$ Ordovician, $\mathrm{S}=$ Silurian, $\mathrm{D}=$ Devonian, $\mathrm{M}=$ Mississippian, $\mathrm{Pn}=$ Pennsylvanian, $\mathrm{J}=$ Jurassic. Red dashed lines denote the Illinois and Michigan structural basins. Black lines with double arrows indicate the positions of structural arches. "UMV" indicates the location of the Upper Mississippi Valley Lead-Zinc Ore District as defined by Heyl et al. [8]. Blue arrows indicate inferred flow paths of hydrothermal fluids originating in the Michigan basin. Base map modified after [12,13].

Similar MVT mineralization is also present throughout eastern Wisconsin, which was initially thought to represent outlying deposits of the main ore district [14,15]. Limited exploration for MVT mineralization took place in southeastern Wisconsin during the early 1980s through subsurface coring program in eight southeastern Wisconsin counties by Mobil Mineral Resources, Inc. [16]. However, 
extensive Pleistocene glacial overburden, coupled with a limited understanding of the distribution and character of geologic structures and the absence of economic petroleum deposits, has hampered efforts to fully characterize the region's subsurface geology. This article focuses on a broad region of Paleozoic-hosted MVT mineralization in northeastern Wisconsin located about $250 \mathrm{~km}$ (150 miles) northeast of the Upper Mississippi Valley Zinc-Lead ore district and the Illinois basin (Figure 1).

During the 1970s and 1980s, Paleozoic rocks in Wisconsin received further attention from carbonate sedimentologists who focused on Ordovician rocks as a potential ancient analog for the formation of low-temperature dolomite. This model, known either as the "Dorag" model or the mixing-zone model, involved interaction between fresh water and seawater along a coastal mixing zone in southern Wisconsin [17]. Despite an early call for a hydrothermal origin for the dolomite [18], the low-temperature interpretation continued to be favored by most sedimentologists who worked in the region. In fact, the Dorag model became a paradigm for dolomitization models elsewhere, and remained so throughout much of the 1980s and 1990s (e.g., [19-21]).

The geochemical interpretations for the origin of the dolomite and MVT mineralization in eastern Wisconsin were in stark contrast with one another until conclusive data were presented that supported a hydrothermal origin for both [22,23]. This hydrothermal system was interpreted to be a distinct, unrelated flow system from the one that formed the Upper Mississippi Valley ore district. Subeconomic MVT mineralization extends throughout the entire region of eastern Wisconsin into the Upper Peninsula of Michigan. Luczaj [22,23] used petrographic, isotopic, and fluid-inclusion data to propose a common hydrothermal origin for the MVT mineralization, pervasive epigenetic dolomitization, and K-silicate mineralization in the region. His research mainly focused on an evaluation of the mixing-zone versus hydrothermal epigenetic dolomitization models for the formation of pervasively dolomitized strata in the region.

\subsection{Geologic Setting of the Study Area}

The study area in eastern Wisconsin region lies on the western edge of the ancestral Michigan basin and is located to the east of the Wisconsin arch and to the south of the Superior Craton (Figure 1). As much as 500 to $800 \mathrm{~m}$ of Lower and Middle Paleozoic quartz sandstone, dolostone, and shale are present (Figures 2 and 3), and the strata thicken and dip gently toward the Michigan basin (Figure 4) where they are overlain by younger Paleozoic and Mesozoic sedimentary rocks.

Numerous gentle folds, faults, and fractures are observed in Paleozoic rocks in the region, despite a geographic position near the middle of the North American craton away from orogenic belts. Dip-slip and strike-slip faults are present within the study area, based upon water well records and quarry exposures, but few are directly observed because they are concealed by extensive Pleistocene glacial drift [23-25]. The carbonate rocks throughout the study area are completely dolomitized over all stratigraphic intervals. Faults and joints were certainly preferred conduits for mineralizing groundwater because sulfide minerals are preferentially precipitated along these surfaces throughout most of the study area. Stratigraphic reconstructions and organic maturity data suggest that the thickness of eroded sediments in eastern Wisconsin was probably much less than 1-1.5 km at any time during the burial history of these rocks [23].

\subsection{Origin of the MVT Mineralization in Eastern Wisconsin}

Luczaj $[22,23]$ proposed the existence of a regional hydrothermal system in eastern Wisconsin that was active during the Late Devonian-Mississippian periods. The precise timing is not well defined, but could be earlier than the Late Paleozoic system responsible for mineralization of the Upper Mississippi Valley Zinc-Lead ore district [26]. The rocks in eastern Wisconsin preserve a pervasive hydrothermal signature and contain abundant epigenetic dolomite, subeconomic MVT mineralization, and minor authigenic K-silicate mineralization. Fluid-inclusion, stable isotopic, and petrographic evidence suggests that the MVT mineralization, K-silicate mineralization, and dolomitization in eastern Wisconsin are genetically related to the same regional hydrothermal system that operated 
at temperatures between about 60 and $120^{\circ} \mathrm{C}$, with sulfide mineralization likely occurring between about 80 and $110^{\circ} \mathrm{C}[22,23]$. This ancient system was responsible for precipitation and replacement of a suite of MVT sulfide minerals that includes pyrite and marcasite $\left(\mathrm{FeS}_{2}\right)$, galena $(\mathrm{PbS})$, sphalerite (ZnS), chalcopyrite $\left(\mathrm{CuFeS}_{2}\right)$, fluorite $\left(\mathrm{CaF}_{2}\right)$, and other related minerals. It is this hydrothermal system that also precipitated the arsenic, nickel, and cobalt-bearing sulfide minerals in the region, including unusually enriched sulfide cement horizons (SCH) in sandstones such as the St. Peter Sandstone of the Middle Ordovician Ancell Group (Figure 2).

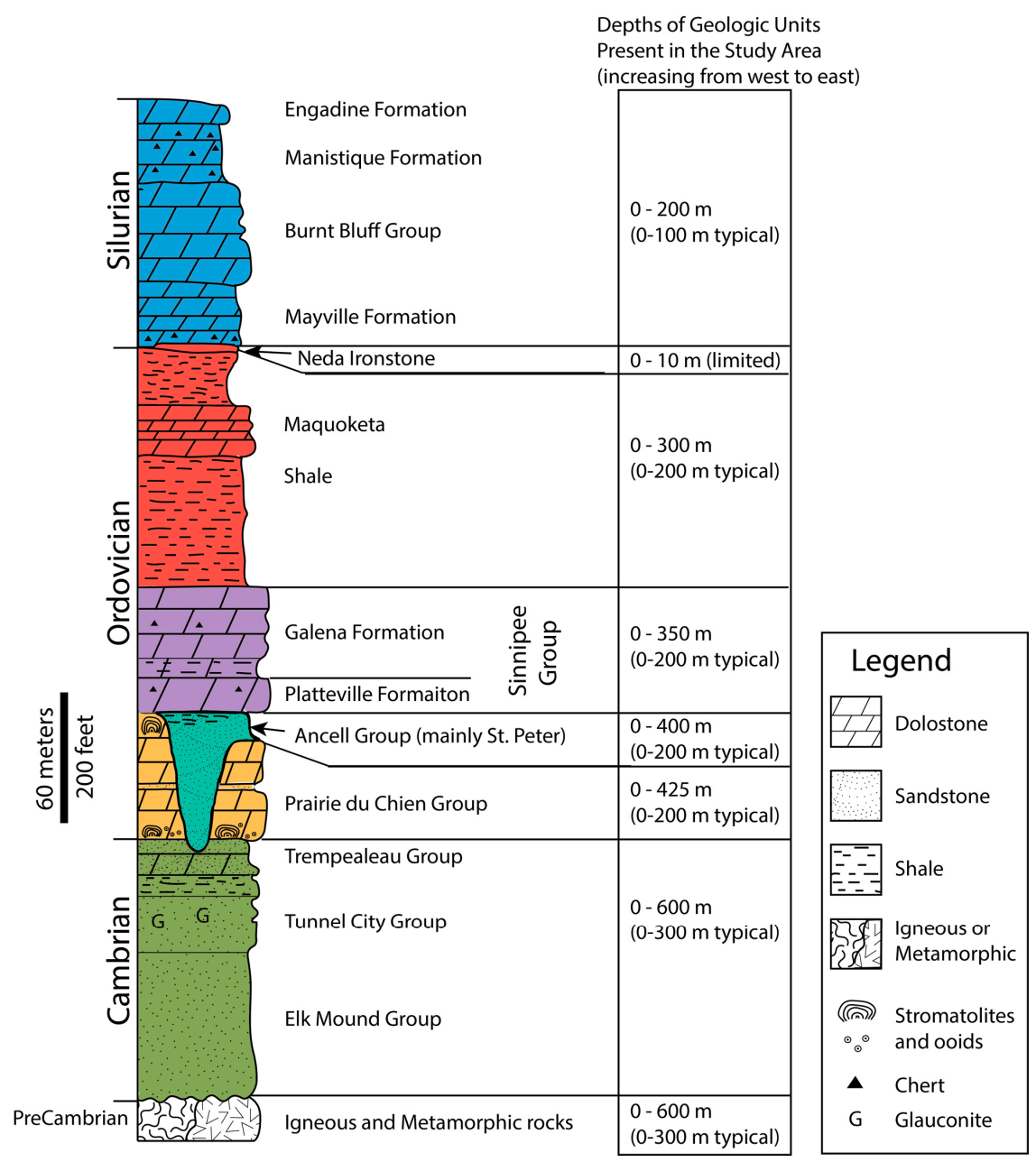

Figure 2. Simplified stratigraphic column for Paleozoic rocks in northeastern Wisconsin, USA [13]. Pleistocene sediments and younger Silurian and Devonian strata for southeastern Wisconsin are not shown here for simplicity, but can be found elsewhere $[27,28]$.

The sequence of mineralization in the study area is somewhat variable, but generally consists of early dolomite and quartz, followed by K-feldspar and MVT mineralization, followed by late calcite. Dolomite precipitation continues throughout the main stage of sulfide mineralization. However, unlike many MVT-related dolomites, the dolomite of eastern Wisconsin is almost exclusively planar (non-saddle). Only a few small vugs with examples of saddle dolomite have been observed in the study area, and cathodoluminescence suggests they have the same cement stratigraphy as some of the planar dolomite [23]. Some late-stage euhedral planar dolomite crystals are up to $1 \mathrm{~cm}$ in diameter. 


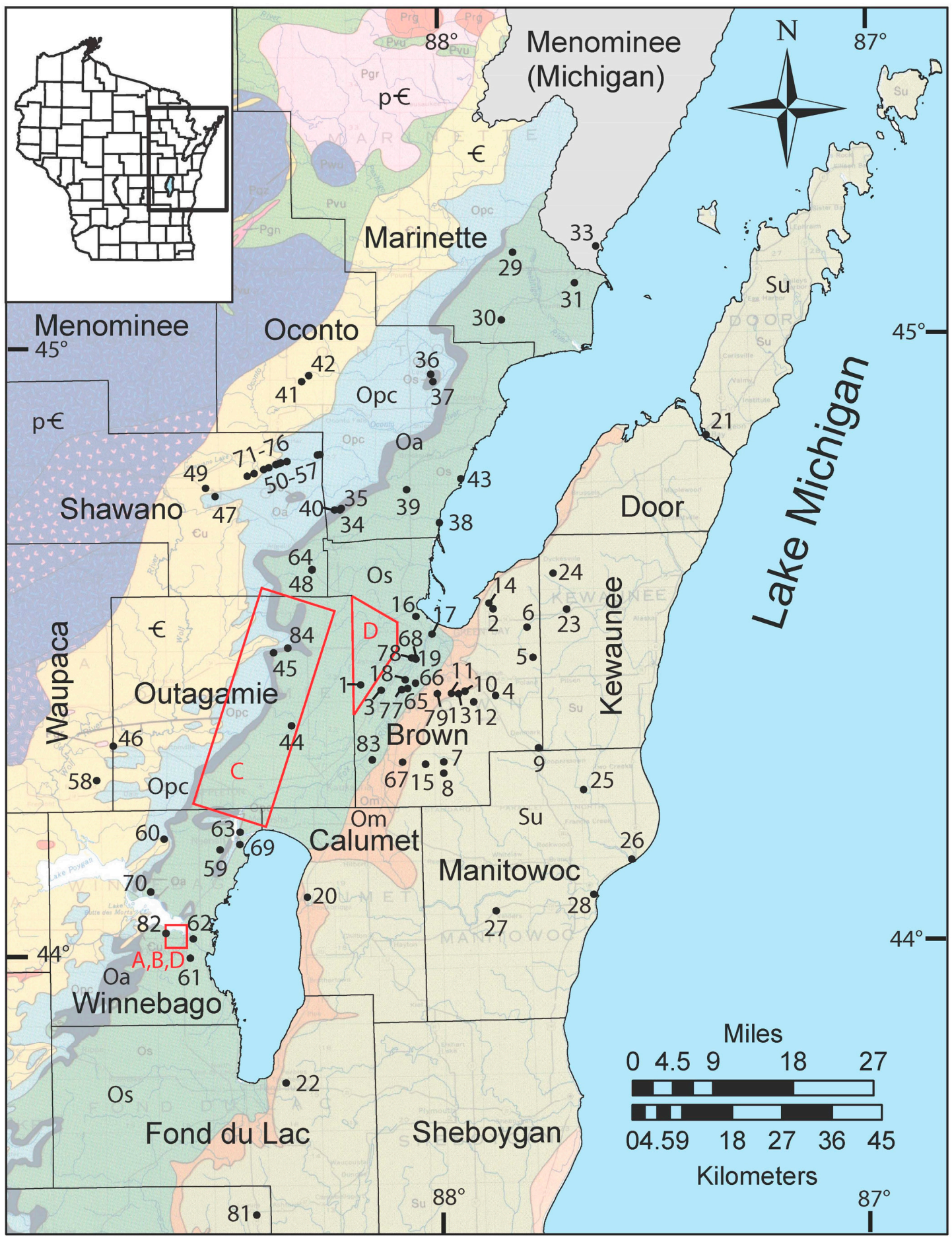

Figure 3. Map with sample locations (outcrops, quarries, drill cores, well cuttings) throughout the study area in northeastern Wisconsin. Thin lines and names indicate county boundaries. Inset map shows the study area location in the state of Wisconsin, USA. Red areas with letters indicate groundwater studies performed in the region (A is reference for Gotkowitz et al. [29], B is Thornburg and Sahai [30], C is Burkel and Stoll [31], and D is Schreiber et al. [32]). Additional references for region-wide studies include Riewe et al. [33] and Johnson and Riewe [34], as well as a cancer study by Knobeloch et al. [35] that focused on Winnebago and Outagamie counties. Base map after Mudrey et al. [36] shows the following units: $\mathrm{pE}=$ Precambrian, $\mathrm{E}=$ Cambrian sandstones, $\mathrm{Opc}=$ Ordovician Prairie du Chien Group, $\mathrm{Oa}=$ Ordovician Ancell Group, Os = Ordovician Sinnipee Group, Om = Ordovician Maquoketa-Neda formations, and $\mathrm{Su}=$ Silurian dolostones. 


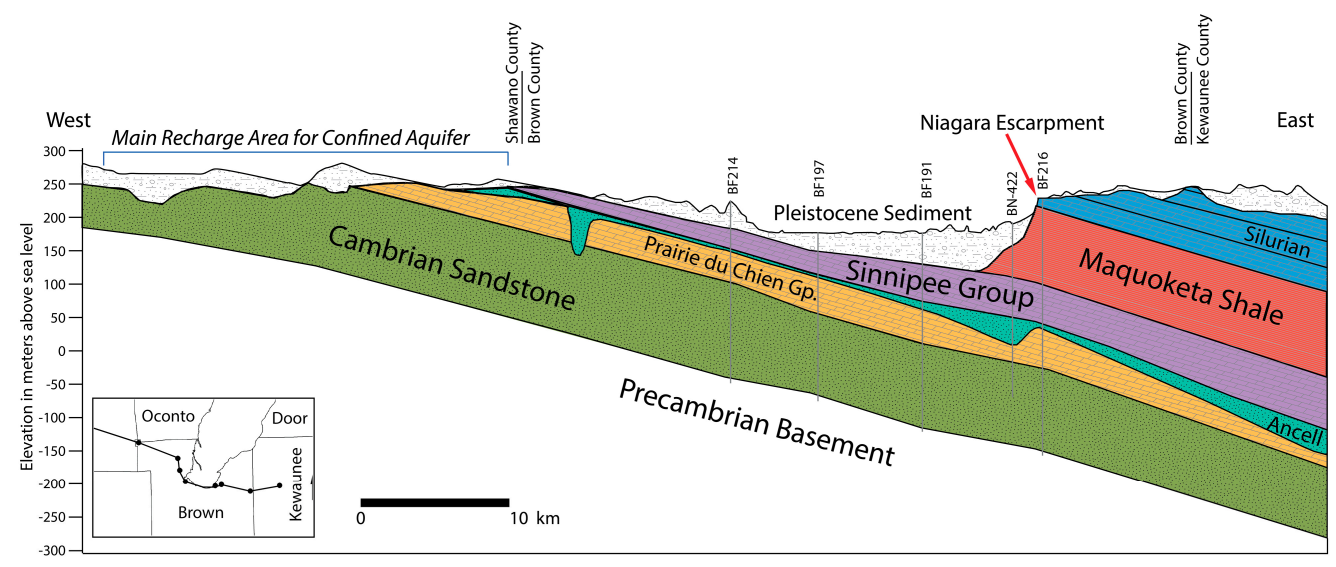

Figure 4. West to east geologic cross-section through portions of Shawano, Brown, and Kewaunee counties near Green Bay, Wisconsin. Paleozoic strata typically dip southeastward between about 5 and $7.5 \mathrm{~m} / \mathrm{km}$ toward the ancestral Michigan basin. Vertical lines with labels indicate well codes for selected existing and backup wells in the Green Bay region of Brown County. Vertical exaggeration is 45 times. Modified after [13].

\subsection{Relevance to Water Quality Issues}

Dissolved arsenic has been recognized as a significant water quality problem that affects millions across the world and can lead to health problems including lung, bladder, and skin cancers. Bangladesh, for example, is widely known for having high dissolved arsenic resulting from sulfide mineralization, with the situation being described as a public health emergency (e.g., [37]). Three main regions in Wisconsin exhibit elevated levels of arsenic in groundwater $[13,35]$. Since its discovery in the late 1980s as part of a routine feasibility study for a landfill proposed in Winnebago County [33], the problem of arsenic contamination in the region's groundwater has received significant attention, with most work occurring in Winnebago and Outagamie counties (Figure 3). Eastern Wisconsin's MVT mineralization is recognized as the source of regionally extensive groundwater contamination in the form of dissolved arsenic, nickel, and other related metals [13]. The focus of previous research in the region [29-34,38-40] was to characterize the distribution and release mechanisms of arsenic in well waters and aquifer host rocks (mainly Ancell Group), primarily in parts of the eastern Wisconsin counties of Winnebago, Outagamie, and Brown (Figure 3). Geochemical mechanisms proposed for arsenic release include oxidation of arsenic-bearing sulfide minerals (most significant), reductive dissolution of iron (hydr)oxides, and release of sorbed arsenic from mineral surfaces [29,30,39].

Arsenic (As) concentrations vary from less than $1 \mu \mathrm{g} / \mathrm{L}$ to over $15,000 \mu \mathrm{g} / \mathrm{L}[33,41]$ in the study area, which contains several tens of thousands of private water wells and hundreds of municipal and other high capacity wells. In some townships (roughly $100 \mathrm{~km}^{2}$ ), $20 \%-40 \%$ of the wells tested above the $10 \mu \mathrm{g} / \mathrm{L}$ health standard set for As in drinking water by the United States Environmental Protection Agency [13]. Although wells are less commonly tested for nickel and cobalt, these metals were also observed in some wells at elevated concentrations, especially in Winnebago and Outagamie counties. An evaluation of publicly available data through the Wisconsin Department of Natural Resources [41] indicates that in four counties in the study area (Winnebago, Outagamie, Brown, and Green Lake), cobalt exceeded the Wisconsin groundwater quality enforcement standard of $40 \mu \mathrm{g} / \mathrm{L}$ in $5.4 \%$ to $8.8 \%$ of the wells tested. Nickel showed a similar pattern, with six counties in the study area (Winnebago, Outagamie, Brown, Marinette, Fond du Lac, and Manitowoc) exceeding the Wisconsin groundwater quality enforcement standard of $100 \mu \mathrm{g} / \mathrm{L}$ in $1.8 \%$ to $5.7 \%$ of the wells tested. The National Uranium Resource Evaluation (NURE) [42,43], an older dataset from 1976 to 1979, also showed elevated dissolved $\mathrm{Ni}, \mathrm{Co}$, and As in the study area. Most of the wells with exceedances draw water from the Cambrian-Ordovician sandstone aquifers, especially the Ancell Group. Even municipal wells in Brown County 240-320 m deep have been impacted by elevated As, Co, and $\mathrm{Ni}$ during aquifer 
storage and recovery (ASR) tests or when valve leaks occurred that allowed oxygenated surface water into the Cambrian aquifer [44-46].

The most seriously impacted well studied in the region was one in northeastern Outagamie County and was drawing from the Ancell Group (St. Peter Sandstone). The well had the following chemistry (tested 1991-1992): $\mathrm{pH}=2.05, \mathrm{As}=4300 \mu \mathrm{g} / \mathrm{L}, \mathrm{Co}=5500 \mu \mathrm{g} / \mathrm{L}, \mathrm{Cd}=220 \mu \mathrm{g} / \mathrm{L}, \mathrm{Cr}=84 \mu \mathrm{g} / \mathrm{L}$, $\mathrm{Ni}=11,000 \mu \mathrm{g} / \mathrm{L}, \mathrm{Al}=15,000 \mu \mathrm{g} / \mathrm{L}$, and $\mathrm{Pb}=400 \mu \mathrm{g} / \mathrm{L}$ [13,41]. The incidence of As, $\mathrm{Co}$, and $\mathrm{Ni}$ in drinking water wells across the study area demonstrates the need for a better understanding of the link between groundwater quality and MVT mineralization in the region.

Additional work by Knobeloch and others [35] (Figure 3) on the health implications of arsenic in the study area has indicated an increased prevalence of skin cancer in the region. In 2004, the Wisconsin Department of Natural Resources designated a "Special Well Casing Pipe Depth Area" for all of Outagamie and Winnebago counties, which included special requirements for drilling methods, disinfection methods, and grouting requirements [13]. Arsenic is a major priority among regulators and local health departments in the region. Less attention has been paid to counties to the north, and they do not have special well casing requirements, despite their nearly identical geology.

The chemistry of a groundwater system is controlled in large part by the composition of its host rock [47]. Sulfide minerals in eastern Wisconsin Ordovician carbonate rocks coat the walls of joints, bedding planes, faults, and macropores in these dolostones [23]. In Cambrian and Ordovician sandstones, sulfides are observed as isolated nodules, stringers, and sometimes as continuous zones of cementation, especially in the Ancell Group. Oxidation of these sulfide minerals has been shown to be the major source of arsenic and other metals of concern in eastern Wisconsin [29,30,39]. This occurs most often near recharge areas where the aquifers are shallow (Figure 4) or in areas of intense drawdown where the aquifer becomes partially dewatered.

While an initial stratigraphic and petrographic framework was known for bedrock mineralization in Winnebago and Outagamie counties, limited data were available regarding the whole-rock and trace element composition of the bedrock, especially in areas to the north in Marinette, Oconto, and Shawano counties (Figure 3). A better understanding of potential sources of groundwater contamination is needed, especially in these rural areas where domestic well supplies are the dominant source of drinking water.

Although the MVT minerals are unlikely to be mined within the study area, they will continue to affect groundwater quality indefinitely. Groundwater is an important source of drinking water in Wisconsin. The percentage of the population that consumes water produced by private or municipal wells ranges from $18 \%$ to $100 \%$ of the population in each county. Overall, approximately $55 \%$ of the population in the study area uses groundwater, with most surface water users limited to a few of the larger municipalities in Brown, Winnebago, and Outagamie counties [48]. Many municipalities in the study area that currently use surface water have wells that penetrate the Cambrian-Ordovician sandstones in the region (Figure 4) that are kept as a backup in the event of a pipeline malfunction.

This article presents an analysis of the regional, stratigraphic, and petrographic distribution of MVT mineralization in Paleozoic rocks of northeastern Wisconsin and had two main objectives. The first was to document the origin and characteristics of the MVT-related mineralization in eastern Wisconsin. This included field and laboratory mineralogical observations along with a regional whole-rock geochemical study of bedrock from several Paleozoic stratigraphic units, with a focus on heavy metals composition. In this context, we present the first evidence in northeastern Wisconsin of discrete nickel- and cobalt-bearing mineral phases, along with a complete list of MVT-related minerals known from the region. A second objective was to provide a regional foundation for current and future groundwater studies in the region in order to better understand the causes of dissolved arsenic and other metals in the groundwater of northeastern Wisconsin. We hope this work will provide a baseline for future economic geologists and groundwater specialists in this region and in others with similar geology. 


\section{Materials and Methods}

The study area includes several counties in northeastern Wisconsin, comprising approximately $13,000 \mathrm{~km}^{2}$ (Figure 3). The sources of rock samples from the study area included quarries, outcrops, well cuttings, and limited drill cores. Design of a sampling strategy for geochemical characterization was affected by two major limitations. First, the distribution of outcrop and core samples was not random in either the stratigraphic or regional sense due to extensive Quaternary glacial deposits throughout the entire study area. Outcrops are more common near escarpments formed where Silurian and Ordovician dolostones overlie weaker shale or sandstone. Quarry locations are preferentially distributed near the base of the Silurian Mayville Formation, near the base of the Platteville Formation, and near the base of the Prairie du Chien Group carbonates (Figure 2). This outcrop distribution inevitably led to a biased stratigraphic sampling. A second limitation was that physical access to samples near quarry high walls is restricted for safety reasons. We made reasonable attempts to sample multiple stratigraphic levels wherever possible, including sets of well cuttings and drill cores.

\subsection{Sample Collection}

For whole-rock geochemical analysis, we collected and designated two principal categories of samples. Samples that were representative of the stratigraphic horizon or those that were taken at random are designated as "Matrix" specimens. Online Supplementary Materials Table S1 contains location numbers and sample descriptions. In contrast, sampling that was deliberately biased in an attempt to analyze the most sulfide-rich materials along fractures, bedding planes, and the SCH are designated as "Enriched".

The Paleozoic stratigraphic section (Figure 2) was divided into six principal stratigraphic units for the purpose of collection and analysis. These are the Cambrian sandstones, the Prairie du Chien Group (PDC) carbonates, the Ancell Group sandstone and shale, the Sinnipee Group carbonates, the Maquoketa Shale/Neda Ironstone, and the Silurian carbonates. Numerous samples were obtained from each of these stratigraphic units.

\subsection{Scanning Electron Microscopy with Energy Dispersive Spectroscopy (SEM-EDS)}

Samples of polished rock slabs, crystal-lined vugs, and well-cutting chips were carbon-coated before analysis. Samples were analyzed with a TESCAN Scanning Electron Microscope (SEM), model VEGA TS 5136SB with an excitation voltage of $30 \mathrm{kV}$. Elemental analysis was conducted using Energy Dispersive Spectroscopy (EDS) on a Genesis Spectrum EDAX detector. SEM images were obtained using backscattered electrons (BSE). This technique was used to explore the chemistry and petrographic distribution of metal sulfide minerals and associated minerals in over 30 selected samples.

\subsection{Whole-Rock Geochemistry and Data Analysis}

Matrix samples submitted for whole-rock analysis were typically 1-2 kg, except for drill cores and cuttings, which typically had a mass of at least $0.02 \mathrm{~kg}$. Specimens indicated as "Enriched" were as large as possible, but generally were at least $0.2 \mathrm{~kg}$. Digestion of 208 whole-rock samples was performed in 2007-2008 by ALS Chemex of Thunder Bay, Ontario, Canada, using Conventional 35-element Inductively Coupled Plasma-Atomic Emission Spectroscopy (ICP-AES) (ALS Method ME_ICP41) after Aqua Regia Digestion in a graphite heating block. Subsequent analysis of an additional 102 samples was performed in 2013 by ALS Minerals of Vancouver, British Columbia, Canada using two methods. Specifically, conventional 51-element ICP-AES (ALS Method ME_MS41) and ultra-low detection ICP-AES (ALS Method ME-MS41L) were performed after Aqua Regia Digestion in a graphite heating block. The results of these analyses yielded whole-rock concentrations for 35 or 51 different elements (depending on analysis), including arsenic (As), cadmium (Cd), cobalt (Co), chromium (Cr), copper $(\mathrm{Cu})$, nickel $(\mathrm{Ni})$, lead $(\mathrm{Pb})$, zinc $(\mathrm{Zn})$, molybdenum $(\mathrm{Mo})$, and vanadium $(\mathrm{V})$. Lower detection limits for some of the elements analyzed improved between 2008 and 2013, but this mostly affected elements 
that were not the focus of this study. Additional "overlimit" analyses, conducted with standard laboratory methods, were required for certain samples in which sulfur $(\mathrm{S})$, iron $(\mathrm{Fe})$, and phosphorous (P) exceeded instrument limits. ALS Minerals is accredited by the Standards Council of Canada and reports analytical precision of $\pm 10 \%$ for the methods used in this study. Quality control procedures included sample duplicates during sample crushing, and sample blanks in every analytical run.

Sample numbers, localities, analytical methods, and whole-rock geochemistry for a selected list of elements are presented in Online Supplementary Materials Table S1. Raw whole-rock geochemistry data for all samples are presented in Tables S2A and S2B.

Correlations were estimated between $\log _{10}$-transformed concentrations for selected elements. Elemental concentrations that were below detection limits were set to 0.55 times their detection limit for a given element to avoid missing data after log transformation [49]. Both Pearson's $r$ and Spearman's $\rho$ (a non-parametric measure of correlation) were calculated as a sensitivity analysis due to some remaining non-linearity between some pairs of elements even after transformation, with both measures available in Supplementary Materials Tables S2C and S2D. R version 3.3.0 for Windows was used for all analyses and the construction of plots.

\section{Results}

\subsection{Field and Core Observations}

Observations made at quarries and outcrops clearly indicate that the regional distribution of MVT mineralization extends throughout the study area northward into the state of Michigan. The most abundant minerals found in vugs and fractures tended to be dolomite and calcite, with quartz present locally. Sulfide mineralization was dominated by pyrite and marcasite, but sphalerite, chalcopyrite, and galena were also observed in hand specimens. Additional macroscopic minerals included fluorite, celestine, strontianite, and barite.

The distribution of sulfide minerals (and related weathering products) in the host sedimentary rocks was heterogeneous, but stratigraphically predictable. Throughout northeastern Wisconsin, the stratigraphic unit with the most sulfide mineralization was the top of the Ordovician Ancell Group (dominated by the St. Peter Sandstone in this portion of the state). This zone of naturally enriched iron sulfide mineralization, known as the Sulfide Cement Horizon ( $\mathrm{SCH}$ ), occurs across eastern Wisconsin from the Illinois border in the south to the Michigan border in the north $([13,23]$, this study). In the study area, the $\mathrm{SCH}$ was exposed on the quarry floors or in sump trenches at several quarries in Shawano, Oconto, Marinette, Outagamie, and Winnebago counties and areas southwest of the study area (Figure 5). No distinct ore deposits made any one part of the study area more concentrated than another. Cores and cuttings also show that the $\mathrm{SCH}$ is present down dip to the east of the outcrop belt, from near the surface in quarries to depths of several hundred meters (Figures 2 and 4). Nodules and intergranular cements of pyrite and marcasite were abundant where this group of rocks is rarely exposed. In one quarry near the city of Oshkosh in Winnebago County, a pink coating of amorphous material similar to erythrite (hydrated cobalt arsenate) and annabergite (hydrated nickel arsenate) was observed as a weathering product near the SCH in the St. Peter Sandstone, and was confirmed by SEM-EDS analysis. Another quarry in Green Lake County (southwest of the study area) contained primarily calcite and sphalerite cement in the SCH. A thin $(\sim 10-50 \mathrm{~cm})$ layer of dark brown shale above the St. Peter Sandstone was interpreted to be the Glenwood Shale and was present at many locations. It contained abundant fine-grained sulfides, including pyritized arthropod and bryozoan fossils in some quarries. 

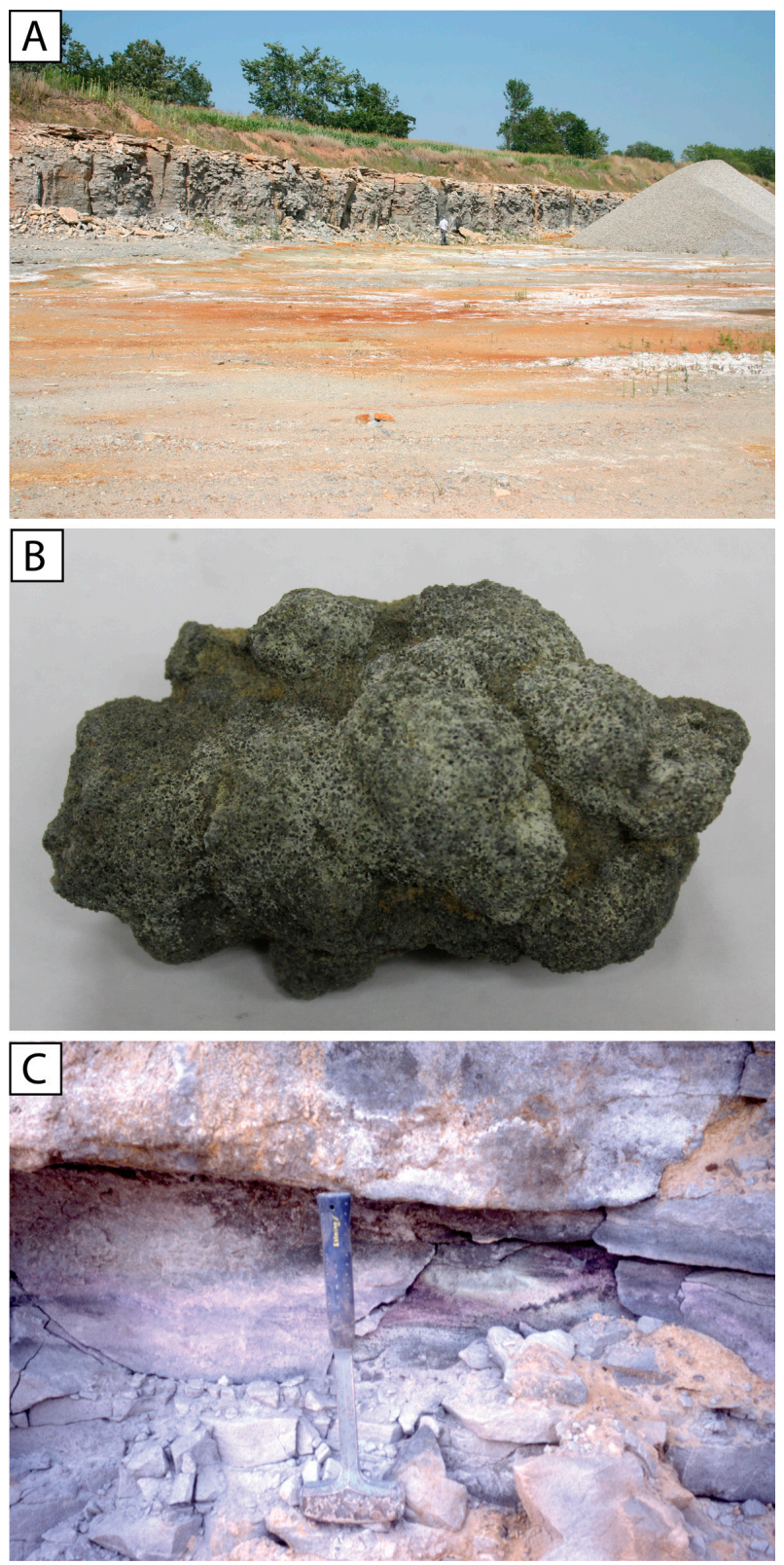

Figure 5. Exposures of the Sulfide Cement Horizon $(\mathrm{SCH})$ in the upper portion of the St. Peter Sandstone (Ancell Group): (A) Discolored floor of a dolostone quarry showing the chemical alteration present at the top of the SCH at Location 34 in Oconto County. The quarry wall is the overlying Platteville Formation of the Sinnipee Group (human for scale). (B) A typical nodule of pyrite and/or marcasite-cemented quartz sandstone from the SCH at Locality 84 in Outagamie County (96-OUT-1), about $9 \mathrm{~cm}$ wide here. (C) Pink coating on Sulfide Cement Horizon at Locality 82 in Winnebago County (hammer for scale).

The next most mineralized stratigraphic zone occurred near the contact between the Silurian Mayville Dolomite and the underlying Ordovician Maquoketa Shale and Neda formations (Figure 6). Where present, the Upper Ordovician Neda Ironstone and related strata appeared to have sulfides associated with the upper extent of those units. In places, the mass of sulfides was striking, with large (10-40 cm thick) accumulations of pyrite easily identified, especially in central Brown County along portions of the Niagara Escarpment. This sulfide mineralization typically extended upward into the lower few meters of the Silurian Mayville Dolomite. In at least one case, a local aggregate producer had problems with the "aesthetic" quality of its product due to rust stains from the weathering of 
pyrite fragments in asphalt and concrete products. This interval was best exposed in quarries and natural outcrops along Scray Hill in the towns of Ledgeview and Glenmore in central Brown County. Significant, but lesser amounts of pyrite were present at this contact and within the upper part of the Maquoketa Formation where the Neda Formation is not present.

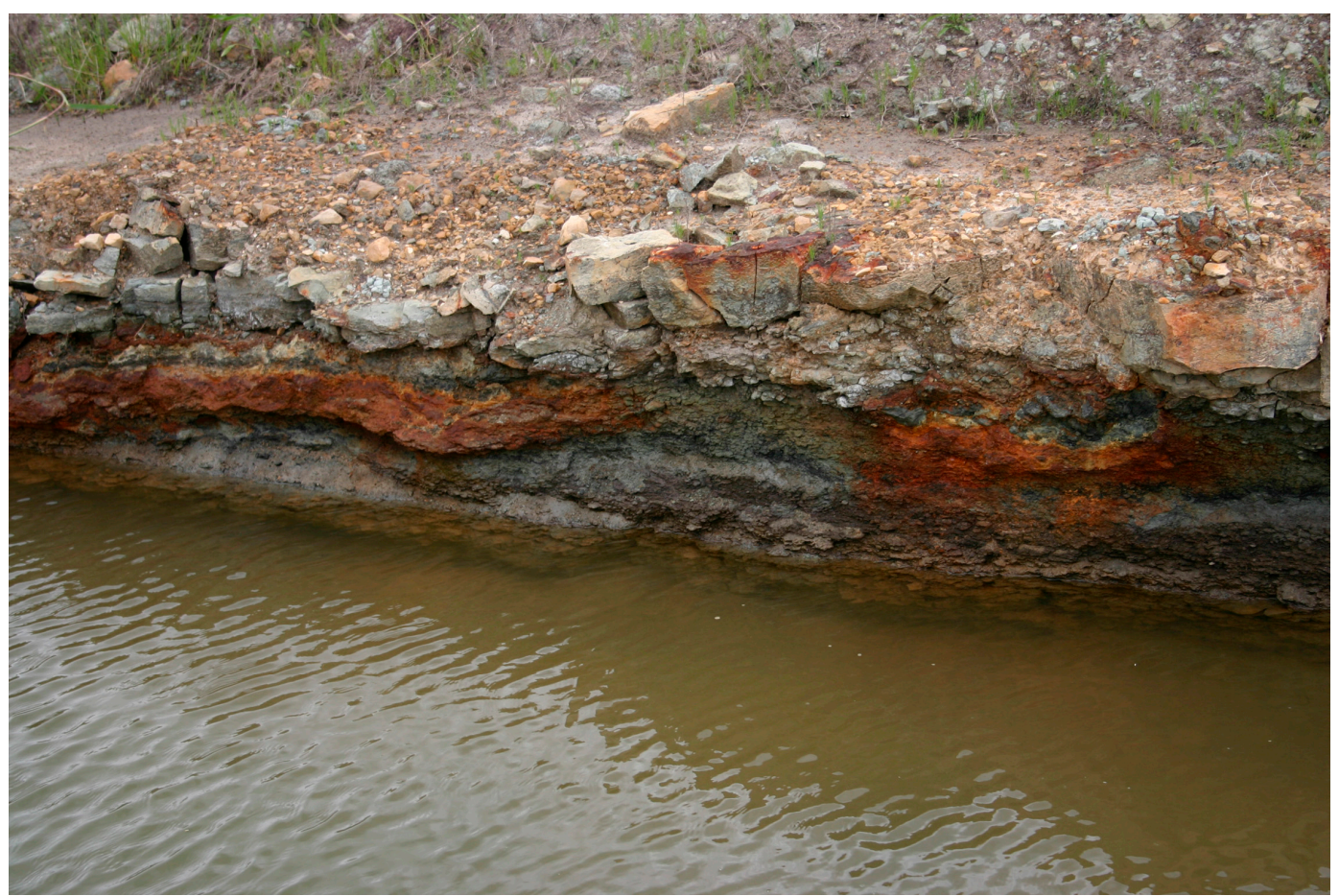

Figure 6. View of an approximately $70 \mathrm{~cm}$ tall section present in a bedrock sump trench at the Scott Construction Ulmen Quarry in central Brown County, Wisconsin (Location 13). Sulfides occur at the contact between the Silurian Mayville Formation (top $30 \mathrm{~cm}$ ) and the Ordovician Neda-Maquoketa formations (lower $40 \mathrm{~cm}$ ) and are responsible for the Fe-oxide staining.

The Ordovician Sinnipee Group carbonates contained significant quantities of metal sulfides, even at stratigraphic intervals farther away from the SCH in the Ancell Group. Sulfide mineralization was locally abundant along bedding planes, in vertical fractures and joints, and as vug fillings and intercrystalline cements. The mineralization was recognized throughout the Sinnipee Group, and some vertical fractures were mineralized by pyrite, K-silicates, and calcite cements throughout over $15 \mathrm{~m}$ of vertical exposure.

Some mineralization occurred within the Prairie du Chien Group and the Cambrian sandstones. Chalcopyrite, quartz, pyrite, and sphalerite were observed in the Prairie du Chien Group, with one notable location in western Outagamie County (Location 46) containing smoky quartz, amethyst, galena and malachite. Pyrite and marcasite nodules were observed in drill cores and cuttings from the Cambrian sandstones, with chalcopyrite, sphalerite, and galena observed locally. The top of the Jordan Sandstone (the uppermost Cambrian unit in northeastern Wisconsin) has also been observed to host zones enriched in pyrite and marcasite [34].

The carbonate units with the least amount of sulfide mineralization were the Silurian dolostones, which represent the youngest strata in the study area. Cores, abundant quarry exposures, and outcrops of the Silurian dolostones indicate that most sulfides are restricted to the lower few meters of the Mayville Formation. However, trace amounts of iron sulfides were present in various forms throughout the Silurian section. The presence of iron-stained vertical joints suggests that this unit, which is regionally karsted, has had much of its sulfide mineralization removed through near-surface weathering during the Cenozoic Era. 


\subsection{Petrographic Analysis Using SEM with EDS}

Samples of polished rock slabs, polished thin sections, crystal-lined vugs, and well-cuttings chips were analyzed to determine minerals present, to outline mineral paragenesis, and to identify whether or not separate mineral phases were present that could be identified as the source of certain heavy metals present in regional groundwater.

Separate mineral phases containing $\mathrm{Fe}, \mathrm{Zn}, \mathrm{Pb}, \mathrm{Cu}$, and other metals were observed in samples from many locations, especially where parts of the middle and lower Ordovician section are exposed (Figures 7-10). Typically, pyrite and marcasite $\left(\mathrm{FeS}_{2}\right)$ were the dominant sulfide phases present. Pyrite exhibited several crystal habits, including cubes, octahedrons, and pyritohedrons up to $1 \mathrm{~cm}$ in length. Marcasite occured as bladed —and sometimes cockscomb - habits with a greenish or bluish metallic, iridescent coating of unknown origin. Sphalerite (ZnS) was the next most commonly observed sulfide phase, with generally rounded, irregular crystals up to $5 \mathrm{~cm}$. Galena (PbS) was far less common, and was typically found as small cubic crystals a few millimeters in size, but crystals up to $1 \mathrm{~cm}$ were also found in the southern part of the study area. Chalcopyrite crystals are 1 to $3 \mathrm{~mm}$ in size and display a typical disphenoid crystal form.

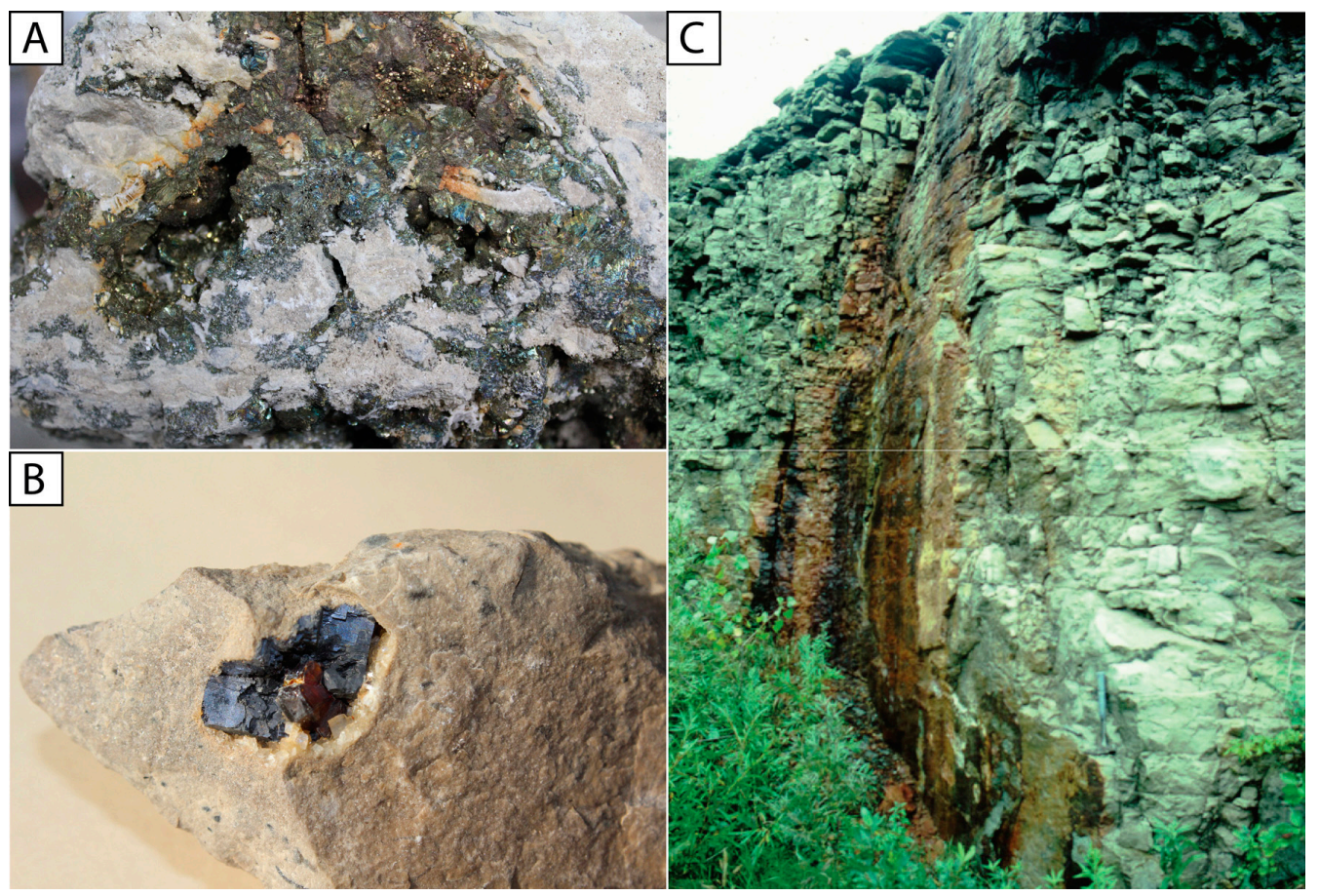

Figure 7. Photographs of selected MVT minerals in Ordovician carbonate strata from northeastern Wisconsin. (A) Fe-sulfide cemented dolostone breccia at Locality 48 . View is approximately $12 \mathrm{~cm}$ across. (B) Dolostone hosted galena and sphalerite with hydrothermal dolomite from Locality 82 in Winnebago County. Vug is $2 \mathrm{~cm}$ across. (C) A small strike-slip fault with several centimeter-wide filling of iron sulfides) at Locality 59 in Winnebago County (note hammer for scale).

Two copper-bearing minerals were observed in the study area. The crystal morphology and EDS spectrum of the most common $\mathrm{Cu}$-bearing phase suggests that it is chalcopyrite $\left(\mathrm{CuFeS}_{2}\right)$. This has been observed at several locations in Oconto, Winnebago, and Outagamie counties (Figures 3 and 9). Botryoidal and fibrous malachite has been observed in growths up to $3 \mathrm{~mm}$ long at one location in western Outagamie County in association with pyrite and chalcopyrite (Figure 9). Malachite has also been observed in association with chalcopyrite south of the study area at the Morris Pit in Green Lake County, Wisconsin [50]. 


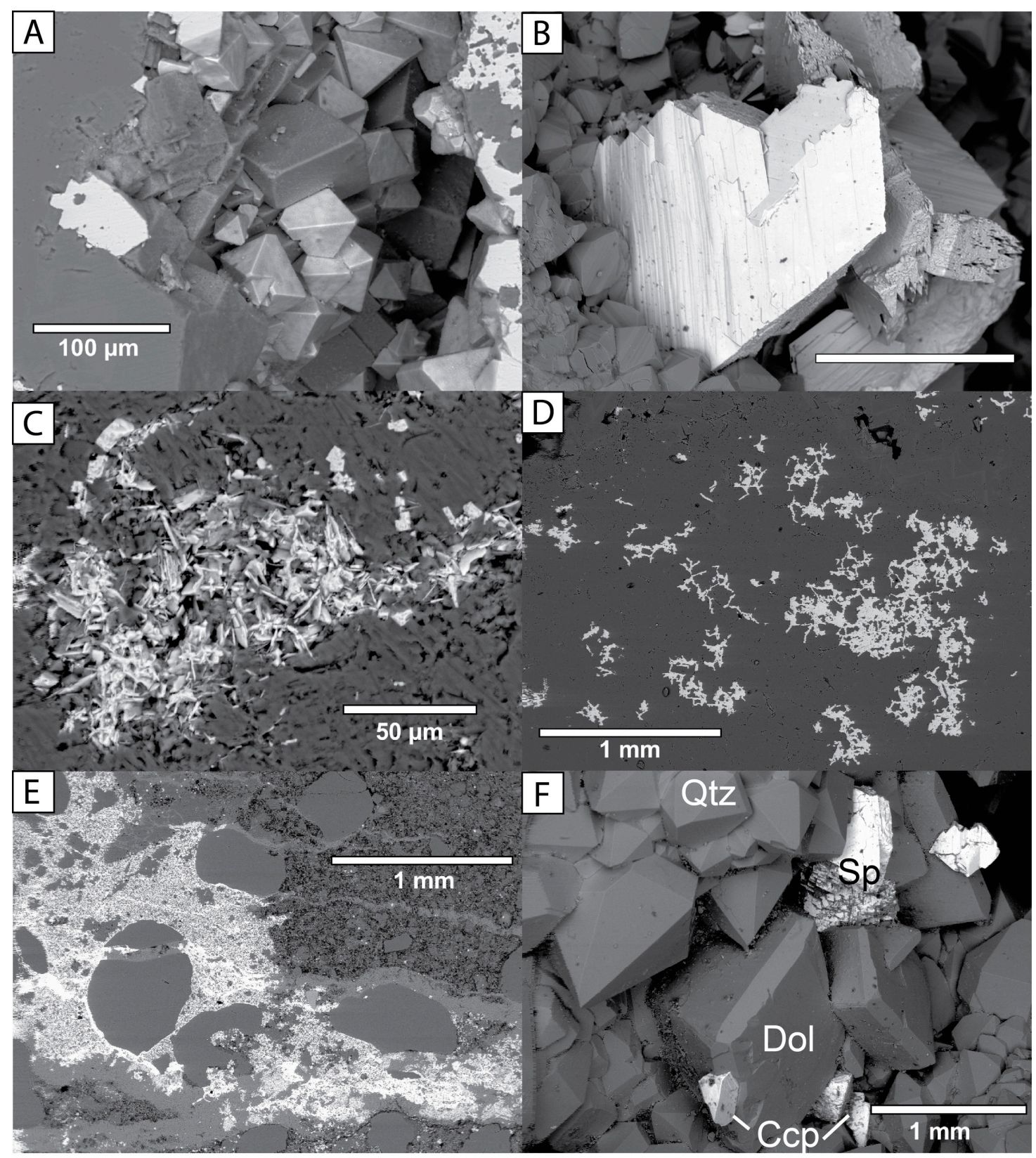

Figure 8. SEM-BSE images of polished sections and vug-filling cements illustrating the character of Mississippi Valley-type mineralization in northeastern Wisconsin: (A) Octahedral pyrite is intergrown with dolomite in vug from Locality 59 in Winnebago County (96-WIN-2). Left and right edges are flat, polished surfaces. (B) Bladed marcasite (bright) on dolomite (gray) from Locality 48 in Shawano County (07-SH-MCK-5). (C) Fine bladed marcasite and cubic pyrite intergrown with dolomite from Locality 48 (07-SH-Mck-0) in Shawano County. (D) Polished section showing dolomite (gray) and later pyrite (bright) filling pores and replacing parts of the dolomite at Locality 3 in Brown County (07-BN-LQ-1). (E) Fracture-filling cements from a quartz sandstone layer in the lower Platteville Formation at Locality 29 in Marinette County (Sample 07-MT-FP-2). Round gray grains are detrital quartz sand. Bright white areas in fracture are pyrite cement, whereas medium gray cements are calcite. Gray spotted areas coprecipitated with pyrite are an unknown authigenic K-Al-Silicate mineral cement, possibly illite or K-feldspar. (F) Late dolomite intergrown with chalcopyrite and sphalerite and associated with quartz from Locality 46 (07-NL-45E) in Outagamie County. 


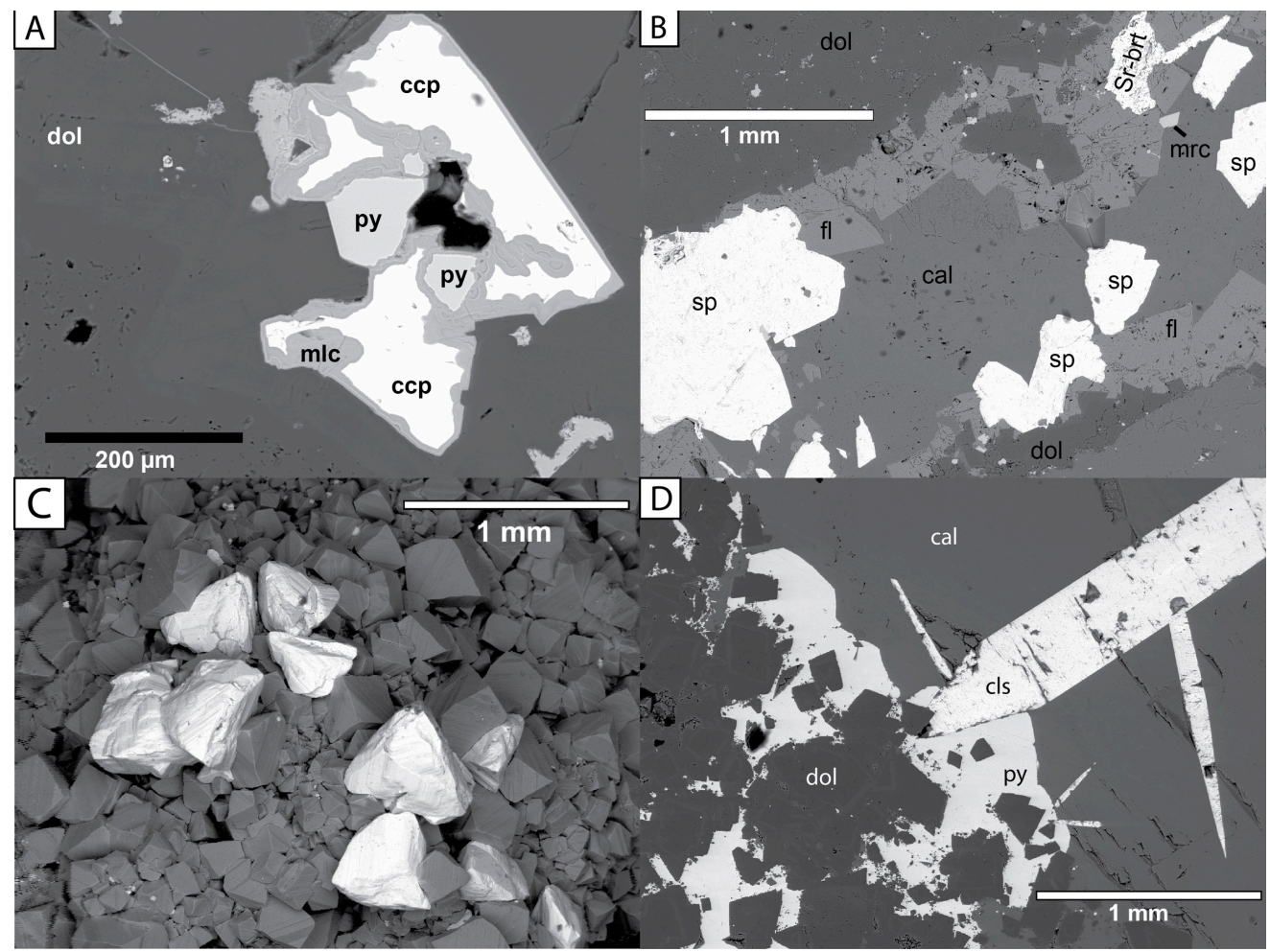

Figure 9. SEM-BSE images of $\mathrm{Cu}, \mathrm{Cr}$, Sr, and Ba-bearing minerals from the study area: (A) polished thin section from Locality 46 in the Oneota Formation (lower Prairie du Chien Group) of western Outagamie County; (B) highly variable mineralogy in a few millimeter-wide fracture from Locality 33 in Menominee County, Michigan; (C) chalcopyrite (bright) on dolomite (gray) from Locality 39 in Oconto County; and (D) an assemblage of dolomite, celestine, pyrite and late calcite from the Platteville Formation at Locality 3 in Brown County. Labeled minerals are dolomite (dol), calcite (cal), botryoidal malachite (mlc), pyrite (py), chalcopyrite (ccp), sphalerite (sp), strontium-barite (Sr-brt), marcasite (mrc), fluorite (fl), and celestine (cls).

The vast majority of pyrite and marcasite analyzed from the region had no detectable peaks for $\mathrm{Ni}$, $\mathrm{Co}$, or As using SEM-EDS techniques. However, detections of $\mathrm{Ni}, \mathrm{Co}$, and $\mathrm{As}$ in sulfide minerals were made in some cases (Figure 10; Table 1). Detection of a discrete As peak was limited to one specimen, with values of $\sim 2$ to 4 weight percent ( $~ 0.5$ to 1 mole percent), based on EDS analysis. Although this is higher than the As concentration described by Thornburg and Sahai [30] for As-bearing pyrite in which isomorphic substitution of As was interpreted, it is still likely that the As occurs in a similar form here, and not in a discrete mineral phase such as arsenopyrite.

Despite its occurrence in southern parts of Wisconsin [8,14,51,52], millerite (NiS) has not been documented in this study area of northeastern Wisconsin. Additional references to minor amounts of millerite, bravoite, violarite, honessite, cobaltite and smaltite are given for the Upper Mississippi Valley lead-zinc district in southwestern Wisconsin by Heyl et al. [8,52].

Detection of numerous microscopic crystals of sulfide minerals enriched in $\mathrm{Ni}$ and $\mathrm{Co}$ was made in samples from Brown and Oconto counties (Figure 10; Table 1). These microscopic occurrences are the first examples of Ni- and Co-bearing minerals found in northeastern Wisconsin. Crystals contain widely varying proportions of $\mathrm{Ni}-\mathrm{Co}-\mathrm{Fe}$, based on SEM-EDS analysis. Figure 11 shows normalized mole percent values for the sulfide minerals containing $\mathrm{Ni}, \mathrm{Co}$, and Fe listed in Table 1. Nickel proportions up to 89 mole percent and cobalt proportions up to 24.6 mole percent suggest that the occurrence of these elements is not simply restricted to isomorphous substitution within pyrite, as appears to be the case with arsenic from a few locations in the study area [30]. Based upon crystal 
morphology and SEM-EDS composition, bravoite and vaesite are the most likely mineral species present for the Ni and Co-rich crystals.

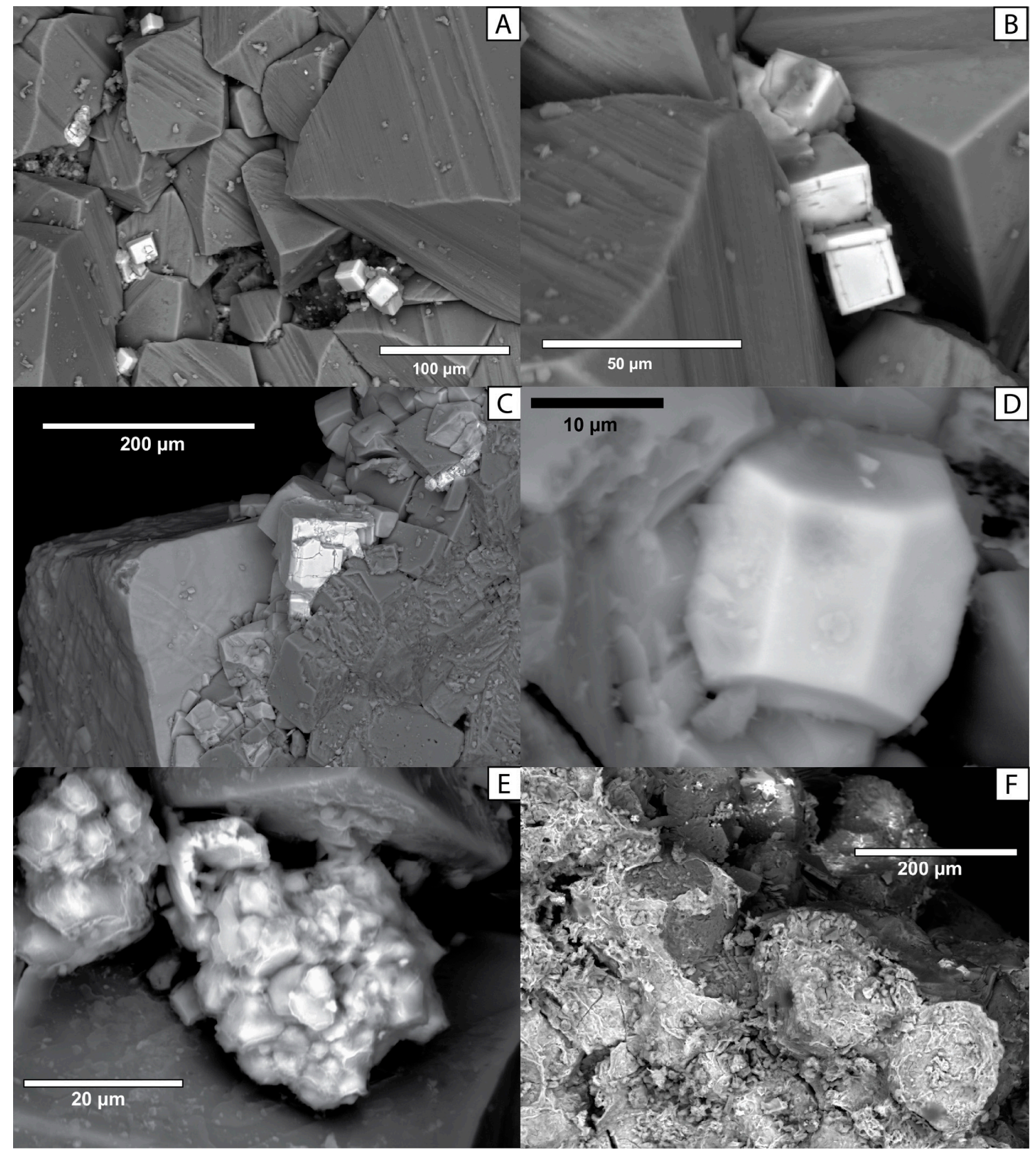

Figure 10. SEM-BSE images of selected $\mathrm{Ni}, \mathrm{Co}$, and As-bearing MVT minerals from three localities in the study area in northeastern Wisconsin. SEM-EDS data for $(\mathbf{A}-\mathbf{E})$ are shown in Table 1: $(\mathrm{A}, \mathrm{B})$ Locality 39 in Oconto County; (C-E) Locality 83 in Brown County; and (F) Locality 82 in Winnebago County. (A) Cubic bravoite (Ni, Co, Fe)S 2 on coarse dolomite (Sample 07-OCO-MTV-2; crystals 3-8). (B) Three crystals of cubic bravoite (2a-c) associated with nickelian pyrite (2d) (Sample 07-OCO-MTV-2; crystals $2 \mathrm{a}, 2 \mathrm{~b}, 2 \mathrm{c}$, and 2d). (C) Bright cubic crystal (center) with regions of both bravoite and vaesite associated with fluorite (medium gray, left) and dolomite (dark gray, lower right) (Sample AP-24; 510-515 ft; crystal 2). (D) Bravoite crystal (Ni, Co, Fe) $S_{2}$ showing both cubic and pyritohedron forms (Sample AP-24; 510-515 ft; crystal 4). (E) Arsenic-bearing nickelian pyrite in finely crystalline masses. Sample AP-24; 520-525 ft; crystal cluster A. (F) Amorphous pink coating of Co-Ni-As-Zn-bearing material (Figure 5) that is likely a sulfate or an arsenide, possibly erythrite (Sample 97-WIN-3). 
Table 1. Concentrations of elements in selected crystals of Ni-Co-Fe-As-sulfide minerals from Brown and Oconto Counties. Values are reported in weight \% generated from the EDAX Software. Sample AP-24 refers to the Village of Wrightstown Test Well in Brown County (Locality 83). Designations 1a, $1 \mathrm{~b}$, etc. refer to analysis points broadly from the core to the rim of crystal 1. Sample 07-OCO-MTV-2 refers to the Montevideo quarry in Oconto County (Locality 39). Dashes indicate no detection by the software.

\begin{tabular}{cccccccccccc}
\hline Sample; Crystal & Ni & Co & As & Fe & C & O & Mg & Si & S & Cl & Ca \\
\hline AP-24; 510-515 ft; 1a & 30.69 & 9.91 & - & 6.22 & 18.19 & 11.49 & - & - & 20.44 & - & 3.05 \\
AP-24; 510-515 ft; 1b & 28.70 & 6.32 & - & 4.62 & 16.30 & 14.16 & - & - & 26.13 & 1.61 & 2.15 \\
AP-24; 510-515ft; 1c & 27.55 & 1.59 & - & 2.80 & 16.78 & 13.07 & - & - & 37.46 & - & 0.76 \\
AP-24; 510-515 ft; 1d & 32.10 & 1.42 & - & 2.77 & 21.33 & 7.13 & - & - & 33.72 & - & 1.54 \\
AP-24; 510-515ft; 2 & 35.31 & 1.49 & - & 2.75 & - & 10.98 & - & - & 49.48 & - & - \\
AP-24; 510-515ft; 3 & 24.55 & 9.98 & - & 5.67 & 17.97 & 14.04 & 1.46 & 0.82 & 20.80 & 2.12 & 2.59 \\
AP-24; 510-515ft; 4 & 17.75 & 3.41 & - & 4.01 & 27.59 & 16.35 & 2.37 & - & 26.36 & - & 2.15 \\
AP-24; 520-525 ft; A1 & 1.84 & 0.75 & 2.27 & 13.08 & 43.34 & 24.47 & 3.06 & 0.45 & 7.89 & 0.66 & 2.18 \\
AP-24; 520-525ft; A2 & 3.16 & 1.36 & 4.09 & 19.41 & 35.64 & 20.57 & 3.44 & 0.50 & 7.36 & 0.59 & 3.90 \\
07-OCO-MTV-2; 1 & 20.25 & 1.41 & - & 4.21 & 19.68 & 23.93 & 1.77 & - & 27.06 & - & 1.68 \\
07-OCO-MTV-2; 2a-1 & 18.99 & 0.90 & - & 3.95 & 25.00 & 25.00 & - & - & 25.36 & - & 0.80 \\
07-OCO-MTV-2; 2a-2 & 15.76 & 1.20 & - & 5.55 & 26.04 & 28.08 & 1.06 & - & 21.20 & - & 1.11 \\
07-OCO-MTV-2; 2b & 19.05 & 1.29 & - & 3.99 & 22.83 & 26.25 & - & - & 26.58 & - & - \\
07-OCO-MTV-2;2c & 17.12 & 1.26 & - & 4.71 & 20.19 & 32.61 & - & - & 23.21 & - & 0.90 \\
07-OCO-MTV-2;2d & 2.47 & - & - & 29.70 & - & 31.84 & 2.08 & - & 32.45 & - & 1.47 \\
07-OCO-MTV-2; 3 & 18.66 & 1.23 & - & 4.21 & 25.53 & 26.01 & 1.48 & - & 21.06 & - & 1.83 \\
07-OCO-MTV-2; 4 & 17.66 & 1.61 & - & 4.57 & 32.29 & 20.54 & 1.74 & - & 19.23 & - & 2.35 \\
07-OCO-MTV-2; 5 & 20.80 & 1.50 & - & 4.99 & 32.73 & 20.87 & 1.63 & - & 15.48 & - & 2.00 \\
07-OCO-MTV-2; 6 & 22.24 & 1.65 & - & 4.97 & 32.35 & 20.34 & 1.64 & - & 14.48 & - & 2.33 \\
07-OCO-MTV-2; 7 & 21.19 & 1.38 & - & 3.75 & 26.49 & 20.64 & - & - & 26.54 & - & - \\
07-OCO-MTV-2; 8 & 15.00 & 1.24 & - & 4.37 & 29.88 & 27.63 & - & - & 20.90 & - & 0.98 \\
07-OCO-MTV-2;9 & 15.27 & 1.13 & - & 4.25 & 20.90 & 30.33 & 2.89 & 0.65 & 22.91 & - & 1.67 \\
\hline
\end{tabular}

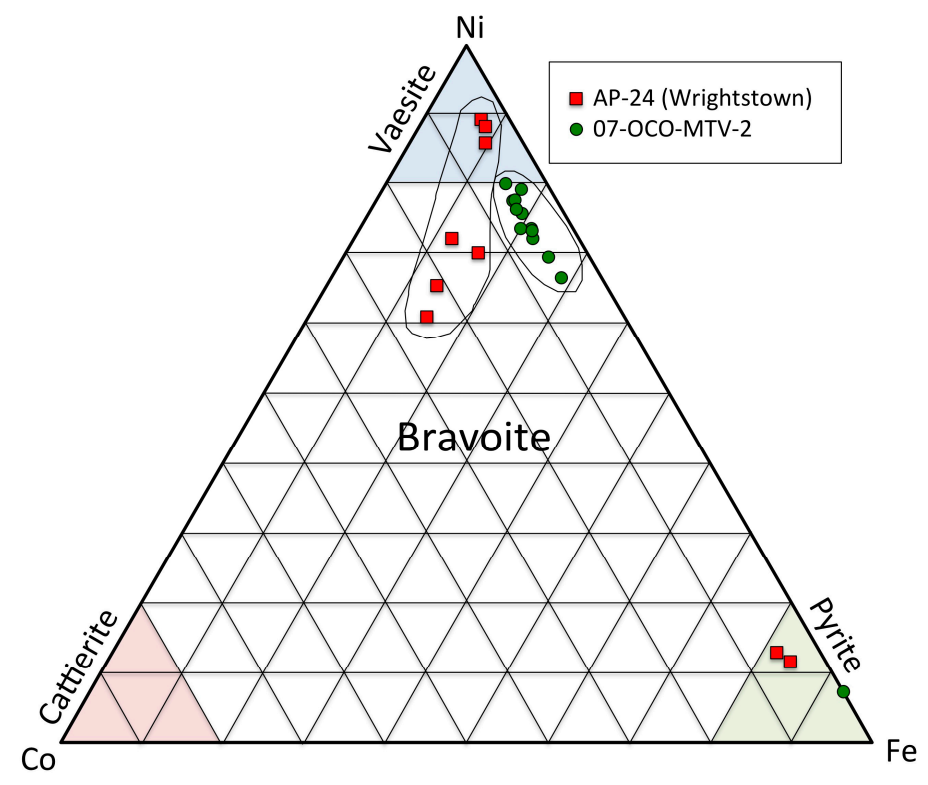

Figure 11. Ternary plot of mole percent normalized compositions indicating the relative proportions of nickel, cobalt, and iron for various members of the pyrite group. Data are for samples listed in Table 1. Red squares are for samples AP-24 (Locality 83), and green circles are for 07-OCO-MTV-2 (Locality 39). Region of bravoite, along with end members pyrite, vaesite, and cattierite are shown, as described by Kerr [53].

The precise mineralogy of these $\mathrm{Ni}$ and Co phases is challenging to determine due to the size of the crystals (tens of micrometers). Crystal morphology varied from indistinct to cubic to cube-pyritohedron 
forms (Figure 10), which is possible in the solid solution series of the pyrite group. In cases where the crystal approaches the $\mathrm{NiS}_{2}$ end-member composition, the mineral vaesite $\left(\mathrm{NiS}_{2}\right)$ is the most likely candidate [53]. Other crystals with elevated $\mathrm{Co}$ and Fe are best described as bravoite $\left((\mathrm{Ni}-\mathrm{Co}-\mathrm{Fe}) \mathrm{S}_{2}\right)$. In the absence of X-ray data, strict identification of these minerals is not possible, but their compositions are shown in Figure 11.

In contrast to the above metals, none of the samples examined with the SEM displayed separate mineral phases for arsenic, such as arsenopyrite. While the presence of arsenopyrite cannot be ruled out in these rocks, it seems likely that As is substituting for Fe as a trace element in the iron sulfides, as has been suggested by Thornburg and Sahai [30]. For a limited sample set, they concluded that As was present in isomorphous substitution with pyrite/marcasite, which can be released by oxidation and subsequently sorb onto ferric oxyhydroxides.

Some fractures and vugs contained a complex microscopic array of minerals in the MVT assemblage (e.g., Figure 9B). In one $2 \mathrm{~mm}$-wide fracture intercepted by a drill core, sphalerite, galena, fluorite, dolomite, marcasite, Sr-barite, and calcite were observed in close association with each other.

With only one exception near the Wisconsin-Michigan border (Locality 33), all galena observed in northeastern Wisconsin falls south of an east-west regional fault that is possibly associated with a crustal boundary in the Precambrian basement rocks known as the Spirit Lake Tectonic Zone [25]. The reason for this distribution is unknown, but it might be related to the metals concentrations in Precambrian bedrock through which hydrothermal deep groundwater likely passed [54,55].

\subsection{Paragenetic Sequence of Mineralization}

Table 2 lists the diagenetic minerals observed in Paleozoic sedimentary rocks in the region. Although no single diagram can precisely synthesize the full complexity of the mineral paragenesis in the study area, Figure 12 illustrates the general mineralization sequence in northeastern Wisconsin.

Table 2. Complete list of Mississippi Valley-type and associated diagenetic minerals observed in Paleozoic rocks of northeastern Wisconsin.

\begin{tabular}{cl}
\hline Mineral Group & Minerals Observed $^{\mathbf{1}}$ \\
\hline Carbonates & Dolomite, calcite, strontianite, malachite (rare) \\
\hline Sulfates & Barite, celestine, Sr-barite, gypsum; anhydrite ${ }^{2}$ (minor) \\
\hline Sulfides (and related) & $\begin{array}{l}\text { Pyrite, marcasite, sphalerite, chalcopyrite, galena, bravoite, } \\
\text { vaesite, nickelian-pyrite, As-bearing-pyrite, erythrite? }\end{array}$ \\
\hline Phosphates & Apatite/fluorapatite \\
\hline Silicates & Quartz, K-feldspar, illite?, amethyst ${ }^{3}$, smoky quartz $^{3}$ \\
\hline Halides & Fluorite
\end{tabular}

${ }^{1}$ Additional rare MVT and alteration minerals not observed in this study can be found in [40] for one quarry in Winnebago County; ${ }^{2}$ Anhydrite was identified in one sample with the assistance of David Tuschel using Raman spectroscopy at HORIBA Scientific in Edison, New Jersey, USA; ${ }^{3}$ Amethyst and smoky quartz were observed at Locality 46 in western Outagamie County.

In general, pervasive dolomitization and silicate mineralization are the earliest events. Early quartz appears to have formed at temperatures $\leqslant \sim 50{ }^{\circ} \mathrm{C}$, due to the presence of all-liquid fluid inclusion assemblages entrapped within quartz overgrowths. Later quartz and the majority of the dolomite were formed from a Na-Ca-Mg-Cl brine at temperatures of $\sim 80-100{ }^{\circ} \mathrm{C}$ as temperatures warmed [23]. Iron sulfides occurred throughout much of the sequence, but the main stage of MVT mineralization included sphalerite, galena, chalcopyrite, pyrite, marcasite, and Ni-Co-Fe-sulfide minerals (Figures 8-10). The MVT mineralization was intergrown with two episodes of dolomite, with most MVT minerals closely associated with late planar dolomite (Figures 7 and 8). Middle and late-stage dolomite, as well as MVT minerals, appear to have formed by similar brines at temperatures 
of $80-110^{\circ} \mathrm{C}$ during what appears to be peak heating. Siderite was not documented in the region, although some dolomite was ferroan. The timing of K-silicates (K-feldspar and possibly illite), relative to other diagenetic phases, is difficult to determine in cases where it occurs as cements within quartz arenites. However, some of it is clearly coeval with abundant iron sulfide mineralization in vertical fractures observed in the northern part of the study area (Figure 8E).

New evidence (Figure 9) suggests that at least some of the sulfate minerals precipitated during the MVT stage of mineralization. Sr-barite, barite, and celestine were observed with fluorite, sphalerite, and pyrite in some samples, likely forming during the waning stages of mineralization. Other late-stage minerals include beef-vein and intergranular gypsum, as well as late-stage calcite. Conditions of calcite mineralization are not well known, but at least some late calcite in Silurian rocks contains all-liquid inclusions, suggesting a lower temperature of entrapment [23]. Strontianite was also found in the region as a relatively late mineral, but its precise location in the sequence is not well-constrained.

The order of mineralization shown in Figure 12 should be used with caution. As a regionally derived diagram, local or stratigraphic variations may not be expressed fully. Many minerals are also found as isolated occurrences or with only one other mineral. Nevertheless, the diagram presents the only complete synopsis of the paragenetic sequence of mineralization in the study area.

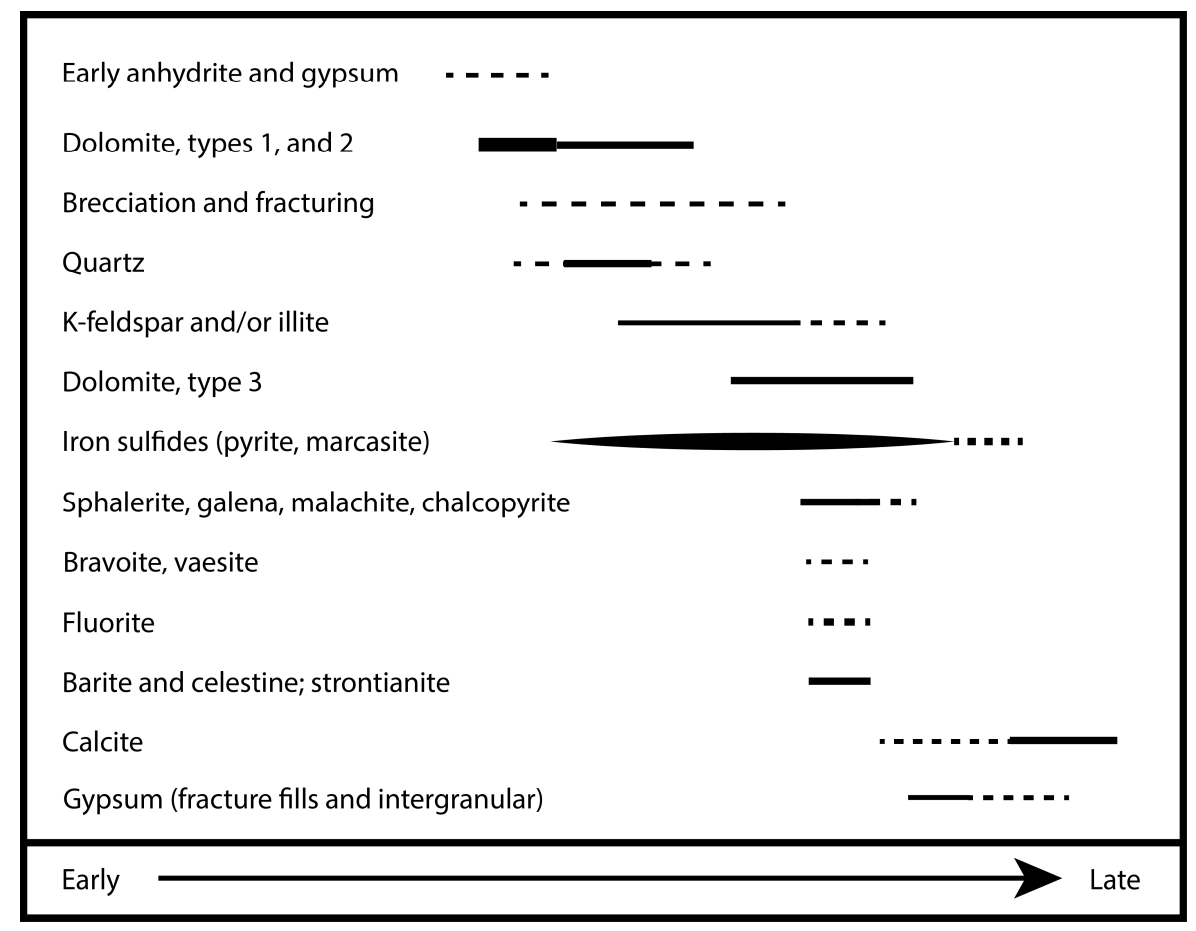

Figure 12. Generalized paragenetic sequence for Paleozoic rocks in northeastern Wisconsin.

\subsection{ICP-AES Analytical Results and Discussion}

Analytical results for all 310 samples are presented in Online Supplementary Materials Tables S1 and S2. The main purpose for analyzing the whole-rock chemistry of these strata was to look for regional and stratigraphic trends in the character of the mineralization, with a focus on heavy metals. Table 3 presents descriptive statistics for selected metals in all samples in the study that were designated as "Matrix" and "Enriched." Table 4 illustrates the typical (median) whole-rock concentrations for selected metals in representative "matrix" samples of bedrock from the region. Averages were not calculated because the data were heavily skewed right, as is common when measuring concentrations. Metals concentrations varied widely, from below detection limits to far above the median concentrations for the host rocks, which was consistent with observations of hand specimens and thin sections. 
Table 3. Minimum, minimum detected, median, maximum, and the interquartile range of concentrations for iron and trace metals in Paleozoic whole-rock samples from northeastern Wisconsin. For Fe, the unit is percentage, while all other elements are measured in $\mathrm{mg} / \mathrm{kg}$ (ppm). Reported values are for all samples in the study (matrix and enriched, $n=310$ ). ND is a value below the detection limit for that respective element.

\begin{tabular}{cccccccccccc}
\hline & Fe (\%) & As & Cd & Co & Cr & $\mathbf{C u}$ & Mo & Ni & Pb & V & Zn \\
\hline Minimum ${ }^{\mathbf{1}}$ & 0.06 & ND & ND & ND & ND & ND & ND & ND & ND & ND & ND \\
Minimum detected value & 0.06 & 0.40 & 0.001 & 0.40 & 1.0 & 0.9 & 0.05 & 0.7 & 0.38 & 1.0 & 0.6 \\
Median & 0.57 & 4.00 & ND & 1.66 & 4.0 & 5.0 & 0.10 & 3.0 & 4.00 & 6.0 & 3.0 \\
Maximum & 28.4 & 499 & 4.20 & 133 & 152 & 1620 & 25.0 & 1110 & 584 & 353 & 3720 \\
Interquartile range & 0.89 & 9.00 & 0.01 & 2.58 & 4.9 & 9.5 & 0.90 & 8.0 & 7.41 & 6.0 & 6.0 \\
\hline
\end{tabular}

${ }^{1}$ Some analyses from early in the study were below the detection limits for many metals due to the analytical methods available.

Table 4. Median metal concentrations (interquartile range in parentheses) for matrix samples from Paleozoic rock strata of northeastern Wisconsin (sample sizes in parentheses next to strata names). For $\mathrm{Fe}$, the unit is percentage, while all other elements are measured in $\mathrm{mg} / \mathrm{kg}$ (ppm). A Precambrian data point was excluded from this table due to having only one observation in that geologic unit.

\begin{tabular}{ccccccccccc}
\hline Rock Unit & Fe (\%) & As & Co & $\mathbf{C r}$ & $\mathbf{C u}$ & $\mathbf{M o}$ & $\mathbf{N i}$ & $\mathbf{P b}$ & $\mathbf{V}$ & $\mathbf{Z n}$ \\
\hline \multirow{2}{*}{ Silurian (33) } & 0.16 & 4.00 & 1.00 & 2.0 & 2.0 & $\mathrm{ND}$ & $\mathrm{ND}$ & 4.00 & 1.0 & $\mathrm{ND}$ \\
& $(0.21)$ & $(6.00)$ & $(0.50)$ & $(2.0)$ & $(2.0)$ & $(0.00)$ & $(1.0)$ & $(3.60)$ & $(2.0)$ & $(3.0)$ \\
\hline \multirow{2}{*}{ Maquoketa-Neda (11) } & 8.52 & 132 & 13.00 & 7.0 & 48.0 & 2.00 & 24.0 & 50.00 & 22.0 & 14.0 \\
& $(13.31)$ & $(151)$ & $(24.50)$ & $(7.0)$ & $(7.0)$ & $(3.34)$ & $(25.1)$ & $(55.15)$ & $(64.0)$ & $(11.0)$ \\
\hline \multirow{2}{*}{ Sinnipee Group (111) } & 0.59 & 2.00 & 1.00 & 3.0 & 3.0 & $\mathrm{ND}$ & 2.7 & 3.60 & 5.0 & 2.0 \\
& $(0.25)$ & $(5.00)$ & $(1.20)$ & $(3.0)$ & $(2.8)$ & $(0.29)$ & $(3.3)$ & $(3.85)$ & $(3.0)$ & $(4.5)$ \\
\hline \multirow{2}{*}{ Ancell Group (18) } & 1.24 & 5.71 & 4.89 & 8.2 & 13.5 & 0.25 & 11.8 & 6.14 & 8.1 & 7.8 \\
& $(1.07)$ & $(4.16)$ & $(6.99)$ & $(13.8)$ & $(12.9)$ & $(0.79)$ & $(31.6)$ & $(8.86)$ & $(14.4)$ & $(8.4)$ \\
\hline \multirow{2}{*}{ PDC Group (75) } & 0.40 & 3.00 & 1.70 & 3.0 & 6.0 & $\mathrm{ND}$ & 2.0 & 2.00 & 9.0 & 3.0 \\
& $(0.17)$ & $(6.00)$ & $(1.25)$ & $(3.0)$ & $(8.0)$ & $(0.24)$ & $(3.0)$ & $(2.95)$ & $(5.9)$ & $(6.5)$ \\
\hline \multirow{2}{*}{ Cambrian (19) } & 0.67 & 1.02 & 3.17 & 12.0 & 6.9 & 1.17 & 5.2 & 1.56 & 6.0 & 2.4 \\
& $(0.68)$ & $(7.35)$ & $(8.69)$ & $(4.6)$ & $(13.4)$ & $(1.11)$ & $(8.0)$ & $(5.07)$ & $(7.2)$ & $(1.4)$ \\
\hline
\end{tabular}

Based on field observations and elemental analysis, three specific stratigraphic horizons showed the most significant mineralization. These were the top of the Ancell Group, the Ordovician-Silurian contact, and, to a lesser extent, the Sinnipee Group dolostone. All three of these zones typically contained elevated metals concentrations, especially in "enriched" samples from the SCH, or along mineralized bedding planes, faults, or fractures. Figure 13 shows box-plots (on the $\log _{10}$ scale) for selected metals from Table 3. Elevated metals occurred in several Cambrian and Ordovician units, but the Silurian dolostones generally exhibited lower concentrations. Additional box-plots for these and other metals are presented in Supplementary Materials Figure S3. It is important to note that all stratigraphic units show some potential for locally elevated metals concentrations, including the Prairie du Chien Group and the Cambrian sandstones, which serve as an important regional aquifer system along with the Ancell Group [56,57].

Table 5 presents Spearman's $\rho$ correlations, estimated for a subset of $\log _{10}$-transformed metals concentrations relevant to the study. Figure 14 shows scatter plots for selected metals concentrations, again on the $\log _{10}$ scale. While most pairs of elements in Table 5 show moderate correlations, the highest values occurred for $\mathrm{Ni}$ vs. Fe, $\mathrm{Ni}$ vs. $\mathrm{Co}, \mathrm{Pb}$ vs. $\mathrm{Fe}, \mathrm{Co}$ vs. $\mathrm{Fe}$, and $\mathrm{Cr}$ vs. V. This result is consistent with the SEM-EDS observations of $\mathrm{As}-$, $\mathrm{Ni}$-, and Co-bearing sulfide minerals, suggesting that they are likely related to the same mineralization event. 

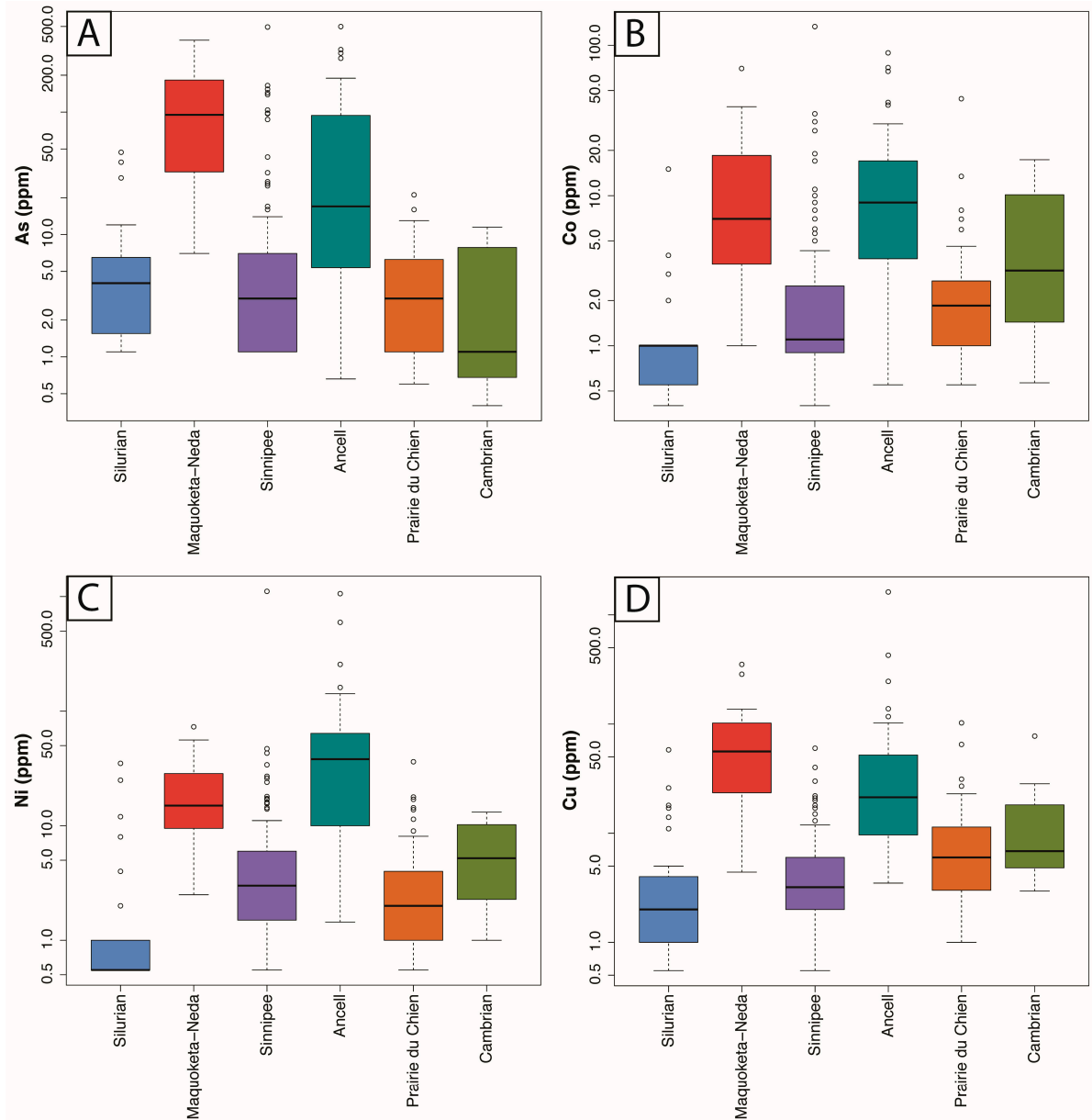

Figure 13. Box-plots on the $\log _{10}$ scale for selected metals ((A) As, (B) Co, (C) Ni, and (D) Cu) for 309 samples (single Precambrian point excluded), separated by major stratigraphic units (Figures 2 and 4). Metals concentrations are highest in the Maquoketa-Neda and the Ancell Group, while the Silurian dolostone units tend to have the lowest concentrations for most metals. Colors correspond to those used in Figures 2 and 4.

Table 5. Estimated Spearman's $\rho$ correlations amongst $\log _{10}$-transformed variables for selected elements. For all but one of the estimates ( $\mathrm{Zn}$ vs. Fe of enriched samples), $p$-values were smaller than 0.02 , with most $<0.0001$. An expanded analysis showing Pearson's $r$, Spearman's $\rho$, and all $p$-values is presented in Supplementary Materials Tables S2C and S2D.

\begin{tabular}{cccc}
\hline $\begin{array}{c}\log _{10} \text {-Transformed } \\
\text { Variables }\end{array}$ & $\begin{array}{c}\text { Spearman's } \rho \text { All } \\
\text { Samples }\end{array}$ & $\begin{array}{c}\text { Spearman's } \rho \text { Enriched } \\
\text { Samples }\end{array}$ & $\begin{array}{c}\text { Spearman's } \rho \text { Matrix } \\
\text { Samples }\end{array}$ \\
\hline Cr vs. V (O-S subset) ${ }^{1}$ & 0.940 & - & - \\
$\mathrm{Ni}$ vs. Fe & 0.744 & 0.587 & 0.642 \\
$\mathrm{Ni}$ vs. Co & 0.718 & 0.690 & 0.654 \\
$\mathrm{~Pb}$ vs. Fe & 0.619 & 0.676 & 0.470 \\
$\mathrm{Co}$ vs. Fe & 0.612 & 0.449 & 0.529 \\
$\mathrm{~K}$ vs. B & 0.594 & 0.694 & 0.578 \\
$\mathrm{Co} v s . \mathrm{As}$ & 0.588 & 0.554 & 0.495 \\
$\mathrm{Cr}$ vs. V & 0.541 & 0.769 & 0.503 \\
$\mathrm{As}$ vs. Fe & 0.522 & 0.579 & 0.313 \\
$\mathrm{Cu}$ vs. Fe & 0.499 & 0.379 & 0.392 \\
$\mathrm{Ni}$ vs. As & 0.437 & 0.540 & 0.201 \\
$\mathrm{Zn}$ vs. Fe ${ }^{2}$ & 0.326 & 0.156 & 0.354 \\
\hline
\end{tabular}

${ }^{1}$ This row represents a subset of 17 enriched and matrix samples from Kittell Falls, Fonferek's Glen, and Ulmen Quarry along a portion of the Niagara Escarpment in central Brown County. Outcrops occur along the Ordovician-Silurian Contact. ${ }^{2}$ The $p$-value for the correlation of $\mathrm{Zn} v s$. Fe for enriched samples was 0.324 . 

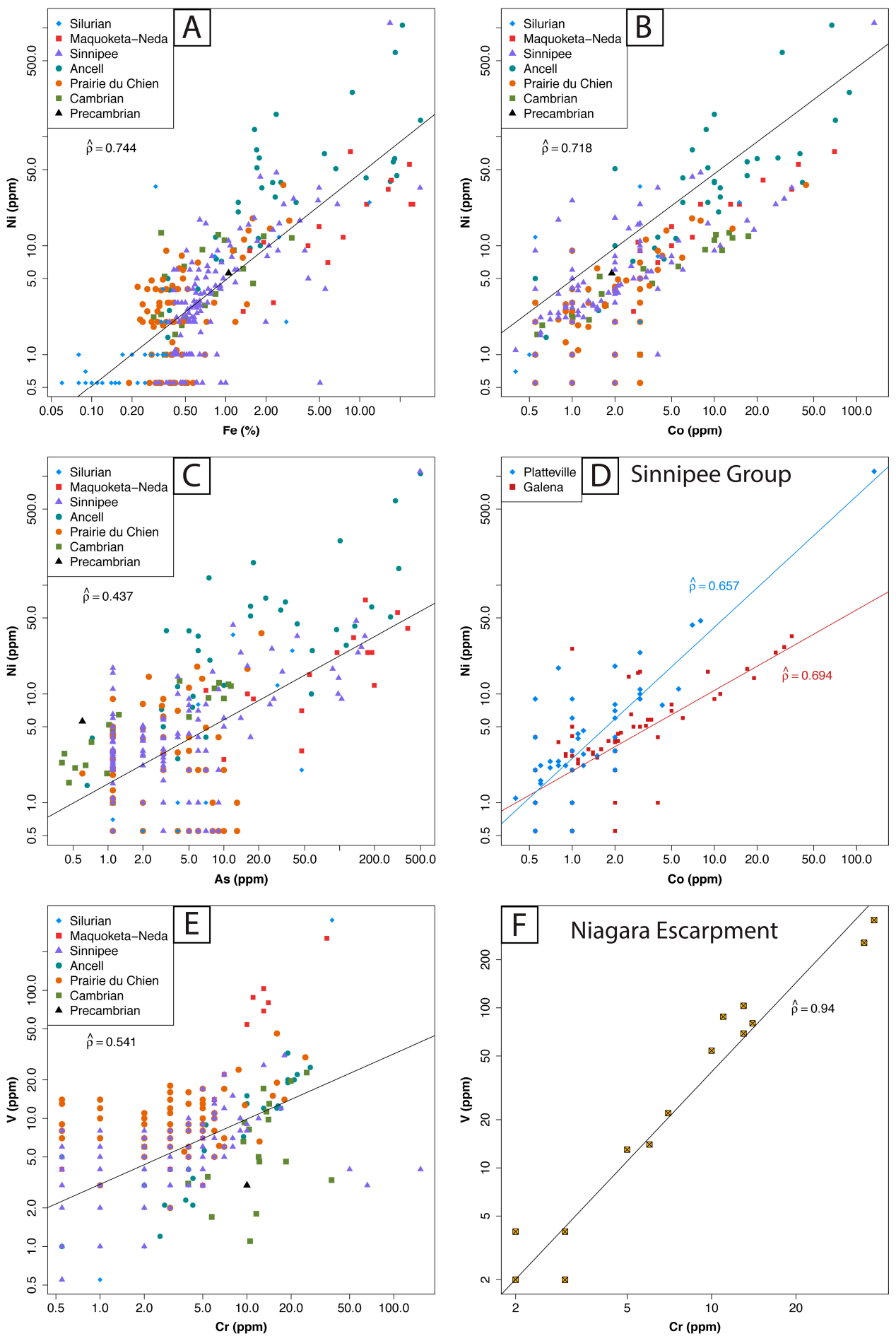

Figure 14. Scatter plots ( $\log _{10}$ axes) of selected metals from whole-rock ICP-AES analyses on rock specimens from northeastern Wisconsin. Legends indicate the particular stratigraphic unit sampled. (A) Nickel (Ni) vs. iron (Fe) for all samples, separated by stratigraphic unit; (B) Nickel (Ni) vs. cobalt (Co) for all samples, separated by stratigraphic unit; (C) Nickel (Ni) vs. arsenic (As) for all samples, separated by stratigraphic unit. Several samples exhibited elevated $\mathrm{Ni}$, consistent with the presence of observed Ni-bearing minerals (see text); (D) Nickel (Ni) vs. cobalt (Co) for the two formations of the Sinnipee Group in northeastern Wisconsin (Platteville and Galena); (E) Vanadium (V) vs. chromium (Cr) for all samples in the study, separated by stratigraphic unit. Note the V-enriched samples (red squares and blue diamond in upper right area of plot) from central Brown County; (F) Vanadium (V) vs. chromium ( $\mathrm{Cr}$ ) for all samples from three localities along a portion of the Niagara Escarpment in central Brown County. 
Strong correlations for Ni vs. Fe $(\hat{\rho}=0.744)$, Ni vs. Co $(\hat{\rho}=0.718)$, and Co vs. Fe $(\hat{\rho}=0.612)$ suggest that these three elements are related to the same mineralization event (Figure 14). Ni and Co are well correlated in all sample subsets (Table 5), suggesting that these elements are more closely related. They are likely principally occurring as isomorphic substitutions in pyrite, or as separate Ni-Co-enriched sulfide minerals. This interpretation is consistent with the discovery of discrete, but microscopic, $\mathrm{Ni}-\mathrm{Co}-\mathrm{Fe}$ sulfide minerals vaesite and bravoite in the study area (Figures 10 and 11). Correlations between $\mathrm{Ni}, \mathrm{Co}$, and Fe are higher than correlations for $\mathrm{Ni}$ and $\mathrm{As}(\hat{\rho}=0.437)$ or Co and As $(\hat{\rho}=0.588)$. This is consistent with mineralogical observations in which As is typically in separate sulfide mineral phases from Ni and Co (Figure 10). This is an important observation suggesting that water quality evaluations for wells in the study area should probably include analyses for Ni and Co more regularly, instead of only As.

Smaller correlations between $\mathrm{Zn}$ and Fe and between $\mathrm{Cu}$ and Fe are most likely due to the fact that those metals also precipitate as separate sulfide mineral phases, such as sphalerite and chalcopyrite, and are independent of the presence of pyrite or marcasite in any particular sample. The same would be expected between $\mathrm{Pb}$ and $\mathrm{Fe}$, but there is a moderate correlation between these two elements $(\hat{\rho}=0.676$ for enriched samples). Because galena is far less commonly observed in the study area than sphalerite, chalcopyrite, pyrite, or marcasite, the correlation between $\mathrm{Pb}$ and Fe may represent isomorphic substitution of $\mathrm{Pb}$ in pyrite or marcasite rather than the discrete presence of galena.

The correlation between $\mathrm{K}$ and $\mathrm{B}$ ( $\hat{\rho}=0.694$ for enriched samples) was unexpected, and is not well understood because boron could not be detected using SEM-EDS techniques. However, it is possible that B is substituting in the structure of authigenic feldspar or illite (e.g., Figure 8E), both of which are present in the region [23]. These minerals could be the source of elevated boron levels reported for the Cambrian-Ordovician aquifer across the study area [58].

Correlations between $\mathrm{Ni}$ and As estimated separately by stratigraphic units (Supplementary Materials Table S2D) showed samples from the Maquoketa-Neda, the Ancell Group, and the Cambrian Sandstones were well correlated $(\hat{\rho}=0.762,0.722$, and 0.797 , respectively). The plot of Ni vs. As (Figure 14C) showed that some samples contained elevated Ni concentrations relative to As. These are best represented by some Ancell Group samples from three Oconto County quarries (Duame Quarry, Chase Quarry, and Montevideo Quarry) and one Sinnipee Group sample from the Vulcan Quarry in Winnebago County. Elevated nickel relative to arsenic is consistent with the existence of Ni-bearing minerals such as vaesite and bravoite that were observed in Oconto County (Figures 10 and 11). Ni and As in the Silurian units appeared moderately correlated $(\hat{\rho}=0.501)$, while in the remaining units (Sinnipee and Prairie du Chien groups), they did not correlate as strongly $(\hat{\rho}=0.381$ and -0.158 , respectively).

Relatively strong correlations between $\mathrm{Ni}$ and Co persisted even for some finer stratigraphic divisions, such as individual formations within the Sinnipee Group. Specifically, for the Galena and Platteville formations, $\hat{\rho}$ was 0.694 and 0.657 , respectively (Figure 14D). As and Co were less strongly correlated for the Galena and Platteville formations, yielding $\hat{\rho}$ values of 0.572 and 0.385 , respectively. Again, this is consistent with the observation of $\mathrm{Ni}$ and $\mathrm{Co}$-bearing mineral phases as described above.

A moderate correlation $(\hat{\rho}=0.541)$ existed for $\mathrm{V}$ and $\mathrm{Cr}$ in all samples over all stratigraphic intervals (Figure 14E), but this correlation improved notably for the enriched sample subset $(\hat{\rho}=0.769)$ (Table 5). However, for a subset of samples from the mineralized zone near the Ordovician-Silurian contact in central Brown County (17 samples along a small portion of the Niagara Escarpment), a particularly high correlation between $\mathrm{V}$ and $\mathrm{Cr}$ was observed $(\hat{\rho}=0.940)$ (Table 5; Figure $14 \mathrm{~F})$. In these samples, a slight enrichment of V, Sc, Tl, and La was also observed. The precise cause is unknown, but it might relate to the presence of oolitic hematite of the Neda Formation along this part of the escarpment. Although there is a general affinity of $\mathrm{V}$ for iron-bearing rocks, most of the samples with high $\mathrm{V}$ concentrations are dolostone samples from near the contact. Another stratigraphic difference noted is that iron sulfide-rich samples from the Maquoketa-Neda contact and the Silurian dolostones just above this contact are depleted in $\mathrm{Ni}$, relative to samples from the Ancell and Sinnipee groups 
(Figure 14A). Although depleted in $\mathrm{Ni}$, they are slightly enriched in $\mathrm{V}, \mathrm{Sc}, \mathrm{Tl}$, and La relative to the Ancell and Sinnipee Group samples (Table S1). These differences are likely the result of diagenesis by hydrothermal groundwater. The Maquoketa Shale (Figures 2 and 4) is a regional confining unit that likely isolated the Silurian dolostone units above from the Ordovician sandstones and carbonates below during mineralization. This local anomaly occurs near the only exposure of the Neda Ironstone, which suggests that mineralizing groundwater may have scavenged certain elements locally from the Neda Ironstone instead of being supplied by groundwater migrating through other strata.

$\mathrm{Cu}$ concentrations were highest in Oconto County (Ancell Group) and near the Ordovician-Silurian contact in central Brown County (Maquoketa-Neda units). This is consistent with the identification of chalcopyrite in field specimens from Oconto County Prairie du Chien Group samples.

Tuttle et al. [59] demonstrated that redistribution of minor and trace elements can occur in rocks with sulfide mineralization due to weathering processes and groundwater flow. While it is likely that remobilization of trace elements may have occurred in the study area, a systematic assessment of this was not performed. Extensive Late Pleistocene glaciation has removed bedrock-derived soil horizons, and most soils have developed on transported materials. In most cases, bedrock samples were obtained from relatively fresh host rocks in quarries, drill cores/cuttings, and excavated road cuts to keep sample weathering effects to a minimum. The most likely bedrock units to have been affected by weathering are the Silurian dolostones (Figure 2), which show extensive karst development [25] and relatively low trace element concentrations (Table 4).

\section{Discussion}

The origin of the SCH is not well understood, but the fact that the most prevalent sulfide mineralization in eastern Wisconsin is located at the top of the St. Peter Sandstone is well recognized. Enrichment of this zone might be the result of sulfate reduction due to organic carbon near the contact between the Ancell and Sinnipee groups, but this is absent at many locations in the study area. Alternatively, its location at the top of the St. Peter Sandstone is consistent with the possibility of a sour gas cap during mineralization. The presence of sour $\left(\mathrm{H}_{2} \mathrm{~S}\right.$-rich) natural gas migrating with deep groundwater discharging out of the Michigan basin (e.g., [23]) could explain the observed regional and stratigraphic spatial distribution of sulfides at the top of this unit. Precipitation of sulfide minerals would be expected to occur at the site of gas exsolution from brines migrating updip or from a metals-bearing fluid mixing with a preexisting sour gas cap. Further analysis is beyond the scope of this study, but work on the sulfur-isotopic characteristics of the sulfide mineralization is ongoing and may help to resolve this.

Previous work on whole-rock chemistry in the region was limited to a small number of samples because those studies were mostly focused on detailed water quality research in a few locations (Figure 3). Results of the whole-rock analyses from this study were compared with reported metals concentrations for the Ancell Group of Winnebago and Outagamie Counties and other localities in northeastern Wisconsin $[29,38,40,60,61]$. This procedure allowed generalized comparisons to be made between rocks in the southern part of the study area to those in the northern portion. Additional unpublished data were obtained from Dave Johnson [45] for 69 selected well cuttings from Cambrian rocks in Brown County. In those samples, nickel, arsenic, and cobalt concentrations were generally low, but values of up to $22.5 \mathrm{ppm}$ for $\mathrm{Ni}, 105 \mathrm{ppm}$ for As, and $93 \mathrm{ppm}$ for Co were detected in different samples, with six samples containing cobalt above $25 \mathrm{ppm}$ [45]. This likely indicates the presence of As, $\mathrm{Ni}$, or Co-bearing minerals at those locations.

Arsenic concentrations relative to iron in this study were compared to those from the studies mentioned above. In general, whole-rock arsenic concentrations varied between $0 \mathrm{ppm}$ and $500 \mathrm{ppm}$ for all studies. However, for three samples reported in previous studies from Winnebago and Outagamie counties, As concentrations ranged between 500 and 743 ppm. While a few samples reported by 
Gotkowitz et al. $[29,40]$ had higher maximum Co concentrations than those in this study, a comparison of As vs. Co data also shows general overlap between the studies.

There were some differences noted between the studies. First, $\mathrm{Cr}$ concentrations in 308 of 310 samples in this study were below $40 \mathrm{ppm}$. The two exceptions were for cuttings samples in a municipal well in central Brown County with Cr concentrations of 66 and $152 \mathrm{ppm}$. In contrast, 18 of 21 samples analyzed in previous studies $[29,40,61]$ were reported to have $\mathrm{Cr}$ concentrations between 100 and 764 ppm, regardless of location, with most concentrations above $200 \mathrm{ppm}$. Because the locations of some of these data overlap those in our study, these high $\mathrm{Cr}$ values seem anomalous and may be due to sample contamination. One value reported by Gotkowitz et al. [29,40] for an unmineralized sample of St. Peter Sandstone had a Cr concentration above 500 ppm, even though the sample had no sulfur and less than $1 \% \mathrm{Fe}$. Because of this anomalous behavior of $\mathrm{Cr}$, we did not attempt to draw any conclusions about the difference in $\mathrm{Cr}$ between our studies and previous studies as they relate to rock geochemistry. It is possible that samples in the previous studies were submitted to a laboratory that crushed the samples with high Cr-steel, which is an alloy known for its toughness and which would be a suitable material for crushing rocks. In this study, contamination of the two higher $\mathrm{Cr}$ cuttings samples from this study by drilling equipment cannot be ruled out.

A comparison of $\mathrm{Ni}, \mathrm{As}$, and $\mathrm{Fe}$ shows general agreement between most samples analyzed in our study and those of Gotkowitz et al. [29,40] and Pelczar [38] (Figure 14A,B). In most samples, As is enriched relative to Ni. However, in some samples, Ni appears elevated relative to arsenic (Figure 14C), which is consistent with the presence of Ni-bearing minerals such as vaesite and bravoite.

It is unknown whether northeastern Wisconsin holds economic concentrations of MVT minerals in Paleozoic bedrock. A lack of significant local enrichment, compared to the former ore district in southwestern Wisconsin, could be due to a number of factors. It is likely that a diffuse hydrothermal fluid flow system was responsible for mineralization in the study area. This is consistent with pervasively dolomitized carbonate rocks in which 100 percent of the host-rock limestone has been replaced, along with a regionally prevalent $\mathrm{SCH}$. However, occasional instances of acidic, metals-rich groundwater in water wells reported in the region suggest alteration of enriched sulfide deposits might occur in local areas. Such instances are observed mainly in areas near the Ancell Group outcrop belt (Figure 3) where oxygenated water interacts with the $\mathrm{SCH}$ or other sulfides due to natural conditions or aquifer drawdown $[29,30,32,34,40]$. Farther east (i.e., down dip) from the outcrop belt (Figure 4), oxidizing conditions are less likely to occur, so limited information about the existence of mineralized zones can be inferred from groundwater chemistry alone. Extensive glacial sedimentary cover, poor knowledge of geologic structures such as folds and faults, and geochemical conditions favoring the stability of sulfide minerals, make detection of larger concentrations of sulfide minerals unfavorable in much of the region. Structural style, as well as hydrothermal fluid composition and intensity may also be factors.

It is useful to consider the potential impact of this mineralization on groundwater quality in the region outside of Winnebago and Outagamie counties where special well casing requirements are established. While the upper Ancell Group is likely to be the most significant source of metals due to the abundance of sulfides and the fact that porous media flow dominates, water quality in all units below the Silurian dolostones should be studied more carefully in the future. Because the distribution of sulfide minerals is highly heterogeneous, their locations and intensities along fractures, faults, bedding planes, and in vugs are difficult to predict locally. Fracture and bedding plane-dominated flow are likely to amplify the interaction between groundwater and sulfide minerals under the right redox conditions. In addition, certain stratigraphic zones of dolostone with high intercrystalline porosity, such as one about $6 \mathrm{~m}$ (20 feet) above the base of the Platteville Formation, also contain abundant Fe-sulfides locally (Figure 7A). For these reasons, the average concentrations of metals within the specific units are probably not so important. Rather, the complex distribution of sulfide minerals, redox conditions, and fluid flow pathways likely has a much larger influence on water quality in the carbonate units. 
Additional MVT-related groundwater quality issues persist in this region that are relevant to this discussion. High dissolved fluoride (up to $3 \mathrm{mg} / \mathrm{L}$ ) and exceptionally high strontium concentrations (over $10 \mathrm{mg} / \mathrm{L}$ ) are present in groundwater throughout parts of the study area, especially in the Cambrian and Ordovician strata [13,56,58]. It is likely that these two ions are related to the presence of fluorite, celestine, and strontianite in the bedrock. Fluorine was not part of the whole-rock chemical analysis package used in this study, but microscopic and macroscopic fluorite was observed in strata from the region. Strontium whole-rock concentrations were generally low (< 200 ppm in 304 of 310 samples), with the highest concentration observed at $731 \mathrm{ppm}$. However, microscopic and macroscopic celestine and strontianite occur in the study area and are the likely sources of high dissolved strontium [13,51,58]. The fact that high whole-rock Sr concentrations were not observed in this study further emphasizes the important conclusion that many of the minerals having negative impacts on water quality in the region are widespread, but heterogeneously distributed.

\section{Conclusions}

This article provides an improved understanding of the bedrock chemistry in northeastern Wisconsin, USA and places it in the context of groundwater quality problems facing the region resulting from sulfide mineralization. Field, laboratory, and SEM-EDS observations; regional whole-rock geochemical sampling; and a stratigraphic analysis were conducted on Paleozoic bedrock. This study provides the first detailed description and whole-rock geochemical analysis of MVT-bearing rocks in northeastern Wisconsin.

Four major conclusions can be drawn from the study. First, we document that an expanded region of sulfide mineralization, previously described in Winnebago and Outagamie counties, extends northward into Brown, Shawano, Oconto, and Marinette counties. This includes both the highly enriched sulfide cement horizon (SCH) at the top of the Ancell Group, as well as disseminated metal sulfides in other parts of the section. It is now clear that the SCH stretches throughout most of eastern Wisconsin and into the upper peninsula of Michigan.

Second, the study provides the first qualitative and quantitative assessment of the stratigraphic distribution of sulfide mineralization and metals concentrations in Paleozoic bedrock in the region. On a local scale (meters to kilometers), the distribution of MVT minerals is heterogeneous because they occur in vugs, fractures, and along particular bedding planes. The two units with the highest metals concentrations are the Ordovician Ancell Group and the Maquoketa-Neda formations. Somewhat lower concentrations of metals generally occur in the Cambrian sandstones, the Sinnipee Group dolostones, and the Prairie du Chien dolostones. The lowest metals concentrations are typically found in the Silurian dolostones in the eastern part of the study area.

We also present the first descriptions of discrete $\mathrm{Ni}$ and Co-bearing mineral phases in northeastern Wisconsin, along with a complete list of MVT-related minerals known from the region, which is more extensive than previously recognized. Field and SEM-EDS investigations have documented the existence of previously unknown minerals for the region, including vaesite, bravoite, malachite, possibly erythrite, and others.

Finally, the results of this study provide a regional foundation for current and future groundwater studies in the region in order to better understand the sources of dissolved arsenic and other metals in the groundwater of northeastern Wisconsin. Based upon the bedrock geochemistry, the potential for groundwater quality problems from arsenic and other metals is greater than previously recognized for counties in the northern portion of the study area. In addition, the discovery of new minerals (bravoite and vaesite) explains the origin of dissolved nickel and cobalt that has been observed in groundwater above State of Wisconsin health standards for over 25 years. We hope this work will provide a baseline for future economic geologists and groundwater specialists in this region and in others with similar geology.

Supplementary Materials: The following are available online at www.mdpi.com/2076-3263/6/2/29/s1, Table S1: Sample numbers, locations, descriptions, and selected whole-rock geochemistry for 310 samples. Table S2A: Full 
raw analytical results for the whole-rock ICP-AES analyses of samples from 2007 to 2008. Table S2B: Full raw analytical results for the whole-rock ICP-AES analyses of samples from 2013. Table S2C: Expanded table showing estimated Pearson's $r$ and Spearman's $\rho$ correlations amongst $\log _{10}$-transformed variables for selected elements in all samples. Table S2D: Table showing estimated Pearson's $r$ and Spearman's $\rho$ correlations amongst $\log _{10}$ -transformed Ni vs. As, listed by stratigraphic interval (Precambrian excluded). Figure S3: Box-plots for selected metals from both the full set of samples and the "matrix" subset of samples.

Acknowledgments: This project was partially funded by the University of Wisconsin Water Resources Institute (Project numbers WR07R0004 and WR12R0004). We thank the numerous quarry operators and private citizens who granted us property access, without which this study would not have been possible. Drill cores were made available by the City of Green Bay, AECOM, and the American Transmission Corporation. Cuttings of wells were made available by the Wisconsin Geological \& Natural History Survey and by GroundSource, Inc. Students Andrea Duca, Andrew Steffel, and Joseph Baeten provided field and/or laboratory assistance. Dave Johnson provided unpublished data for drill cuttings, along with helpful discussions of ideas. John Lyon provided assistance with SEM equipment at UW-Green Bay. Todd Kostman (UW-Oshkosh) provided access to a carbon coater to prepare SEM samples during the early stages of the project. David Tuschel (HORIBA Scientific) assisted with identification of anhydrite using laser Raman spectroscopy. Four reviewers provided valuable criticism of our initial manuscript. External funds were not received to cover the costs to publish in open access.

Author Contributions: John A. Luczaj coordinated field observations and collections, along with SEM investigations, and wrote the majority of the manuscript. Michael J. McIntire assisted with sample preparation and data analysis. Megan J. Olson Hunt performed the statistical analysis and constructed the plots.

Conflicts of Interest: The authors declare no conflict of interest.

\section{Abbreviations}

The following abbreviations are used in this manuscript:

$\begin{array}{ll}\text { MVT } & \text { Mississippi Valley-type } \\ \text { ICP-AES } & \text { Inductively Coupled Plasma-Atomic Emission Spectroscopy } \\ \text { SEM-EDS } & \text { Scanning Electron Microscopy-Energy Dispersive Spectroscopy } \\ \text { SCH } & \text { Sulfide Cement Horizon } \\ \text { PDC } & \text { Prairie du Chien Group }\end{array}$

\section{References}

1. Sverjensky, D.A. Genesis of Mississippi Valley-type lead-zinc deposits. Annu. Rev. Earth Planet. Sci. 1986, 14, 177-199. [CrossRef]

2. Garven, G.; Ge, S.; Person, M.A.; Sverjensky, D.A. Genesis of stratabound ore deposits in the midcontinent basins of North America. 1. The role of regional groundwater flow. Am. J. Sci. 1993, 293, 497-568. [CrossRef]

3. Leach, D.L.; Taylor, R.D.; Fey, D.L.; Diehl, S.F.; Saltus, R.W. A Deposit Model for Mississippi Valley-Type Lead-Zinc Ores. Chapter A of Mineral Deposit Models for Resource Assessment; United States Geological Survey, Scientific Investigations Report. United States Geological Survey: Reston, VA, USA, 2010.

4. Kyle, J.R. Geology of the pine point lead-zinc district. In Handbook of Strata-Bound and Stratiform Ore Deposits; Wold, K.H., Ed.; Elsevier: New York, NY, USA, 1981; Volume 9, pp. 643-741.

5. Leach, D.L.; Sangster, D.F.; Kelley, K.D.; Large, R.R.; Garven, G.; Allen, C.R.; Gutzmer, J.; Walters, S. Sediment-Hosted Lead-Zinc Deposits: A Global Perspective. Econ. Geol. 2005, 561-607.

6. Hitzman, M.W.; Beaty, D.W. The Irish Zn-Pb-(Ba) Orefield; Society of Economic Geologists Special Publication: Littleton, CO, USA, 1996; Volume 4, pp. 112-143.

7. Leach, D.L.; Viets, J.G.; Kozlowski, A.; Kibitlewski, S. Geology, Geochemistry, and Genesis of the Silesia-Cracow Zinc-Lead District, Southern Poland. Society Economic Geolog. Special Publication 1996, 4, 144-170.

8. Heyl, A.V., Jr.; Agnew, A.F.; Lyons, E.J.; Behre, C.H., Jr. The Geology of the Upper Mississippi Valley Zinc-Lead District; United States Geological Survey Professional Paper. United States Geological Survey: Reston, VA, USA, 1959; Volume 309, p. 310.

9. McLimans, R.K. Geological, Fluid Inclusion, and Stable Isotope Studies of the Upper Mississippi Valley Zinc-Lead District, Southwest Wisconsin. Ph.D. Thesis, Pennsylvania State University, State College, PA, USA, 1977.

10. Bethke, C.M. Hydrologic constraints on the genesis of the Upper Mississippi Valley mineral district from Illinois basin brines. Econ. Geol. 1986, 81, 233-249. [CrossRef] 
11. Rowan, E. Thermal and Hydrogeologic History of a Sedimentary Basin: Case Studies in the Illinois Basin, USA, and the Albigeois District, France. Ph.D. Thesis, Université Pierre et Marie Curie (Paris VI), Paris, France, 1998.

12. Catacosinos, P.A.; Daniels, P.A., Jr.; Harrison, W.B., III. Structure, stratigraphy, and petroleum geology of the Michigan basin. In Interior Cratonic Basins; Leighton, M., Kolata, D., Oltz, D., Eidel, J., Eds.; American Association of Petroleum Geologists Memoir: Tulsa, OK, USA, 1990; pp. 561-601.

13. Luczaj, J.; Masarik, K. Groundwater quantity and quality issues in a water-rich region: Examples from Wisconsin, USA. Resources 2015, 4, 323-357. [CrossRef]

14. Bagrowski, B.P. Occurrence of millerite at Milwaukee, Wisconsin. Am. Mineral. 1940, 25, 556-559.

15. Garvin, P.L.; Ludvigson, G.A.; Ripley, E.M. Sulfur isotope reconnaissance of minor metal sulfide deposits fringing the Upper Mississippi Valley zinc-lead district. Econ. Geol. 1987, 82, 1386-1394. [CrossRef]

16. Evans, T.; Wisconsin Geological \& Natural History Survey, Madison, WI, USA. Personal communication, 21 June 2011.

17. Badiozamani, K. The dorag dolomitization model-Application to the middle Ordovician of Wisconsin. J. Sediment. Petrol. 1973, 43, 965-984.

18. Deininger, R.W. Limestone-dolostone transition in the Ordovician Platteville Formation in Wisconsin. J. Sediment. Petrol. 1964, 34, 281-288.

19. Morrow, D.W. Dolomite-Part 2: Dolomitization models and ancient dolostones. Geosci. Can. 1982, 9, $95-107$.

20. Muchez, P.; Viaene, W. Dolomitization caused by water circulation near the mixing zone: And example from the Lower Viséan of the Campine Basin (northern Belgium). In Dolomites: A Volume in Honor of Dolomieu; Purser, B., Tucker, M., Zenger, D., Eds.; Special Publication of the International Association of Sedimentologists: Ghent, Belgium, 1994; pp. 155-166.

21. Dixon, R.J. A hydrogeological assessment of mixed water dolomitization in a confined coastal aquifer; Cambrian-Ordovician deposits, Illinois Basin. Master's Thesis, University of New Hampshire, Durham, NH, USA, 2000.

22. Luczaj, J.A. Epigenetic Dolomitization and Sulfide Mineralization in Paleozoic rocks of eastern Wisconsin: Implications for fluid flow out of the Michigan Basin, U.S.A. Ph.D. Thesis, Johns Hopkins University, Baltimore, MD, USA, 2000.

23. Luczaj, J.A. Evidence against the Dorag (Mixing-Zone) model for dolomitization along the Wisconsin arch-A case for hydrothermal diagenesis. AAPG Bull. 2006, 90, 1719-1738. [CrossRef]

24. Luczaj, J.A. Preliminary Geologic Map of the Buried Bedrock Surface, Brown County, Wisconsin. Wisconsin Geological and Natural History Survey Open File Report. 2011, WOFR2011-02, 1:100000 Scale Map Sheet. Available online: https://wgnhs.uwex.edu/pubs/download_wofr201102/ (accessed on 1 February 2016).

25. Luczaj, J.A. Geology of the Niagara escarpment in Wisconsin. Geosci. Wis. 2013, 22, 1-34.

26. Brannon, J.C.; Podosek, F.A.; McLimans, R.K. Alleghenian age of the Upper Mississippi Valley zinc-lead deposit determined by Rb-Sr dating of sphalerite. Nature 1992, 356, 509-511. [CrossRef]

27. Wisconsin Geological \& Natural History Survey (WGNHS). Bedrock Stratigraphic Units in Wisconsin; Educational Series; Wisconsin Geological \& Natural History Survey: Madison, WI, USA, 2011.

28. McLaughlin, P.I.; Mikulic, D.G.; Kluessendorf, J. Age and correlation of Silurian rocks in Sheboygan, Wisconsin, using integrated stable carbon isotope stratigraphy and facies analysis. Geosci. Wis. 2013, 21, 15-38.

29. Gotkowitz, M.B.; Schreiber, M.S.; Simo, J.A. Effects of water use on arsenic release to well water in a confined aquifer. Ground Water 2004, 42, 568-575. [CrossRef] [PubMed]

30. Thornburg, K.; Sahai, N. Arsenic occurrence, mobility, and retardation in sandstone and dolomite formations of the Fox River Valley, Eastern Wisconsin. Environ. Sci. Technol. 2004, 38, 5087-5094. [CrossRef] [PubMed]

31. Burkel, R.S.; Stoll, R.C. Naturally occurring arsenic in sandstone aquifer water supply wells of Northeastern Wisconsin. Groundw. Monit. Remediat. 1999, 19, 114-121. [CrossRef]

32. Schreiber, M.E.; Simo, J.A.; Freiberg, P.G. Stratigraphic and geochemical controls on naturally occurring arsenic in groundwater, Eastern Wisconsin, USA. Hydrogeol. J. 2000, 8, 161-176. [CrossRef]

33. Riewe, T.; Weissbach, A.; Heinen, L.; Stoll, R. Naturally occurring arsenic in well water in Wisconsin. Water Well J. 2000, 49, 24-29.

34. Johnson, D.M.; Riewe, T. Arsenic and Northeastern Wisconsin. Water Well J. 2006, 60, 26-31. 
35. Knobeloch, L.M.; Zierold, K.M.; Anderson, H.A. Association of arsenic-contaminated drinking-water with prevalence of skin cancer in Wisconsin's Fox River valley. J. Health Popul. Nutr. 2006, 24, 206-213. [PubMed]

36. Mudrey, M.G.; Brown, B.A.; Greenberg, J.K. Bedrock Geologic Map of Wisconsin. 1:1,000,000 Scale Map Sheet; Wisconsin Geological \& Natural History Survey: Madison, WI, USA, 1982.

37. Smith, A.H.; Lingas, E.O.; Rahman, M. Contamination of drinking-water by arsenic in Bangladesh: A public health emergency. Bull. World Health Organ. 2000, 78, 1093-1103. [PubMed]

38. Pelczar, J.S. Groundwater Chemistry of Wells Exhibiting Natural Arsenic Contamination in East-Central Wisconsin. Master's Thesis, University of Wisconsin-Green Bay, Green Bay, WI, USA, 1996.

39. Schreiber, M.E.; Gotkowitz, M.B.; Simo, J.A.; Freiberg, P.G. Mechanisms of arsenic release to ground water from naturally occurring sources, eastern Wisconsin. In Arsenic in Ground Water; Welch, A., Stollenwerk, K., Eds.; Kluwer Academic Publishers: Boston, MA, USA, 2003; pp. 259-280.

40. Gotkowitz, M.B.; Simo, J.A.; Schreiber, M. Geologic and Geochemical Controls on Arsenic in Groundwater in Northeastern Wisconsin; Wisconsin Geological and Natural History Survey Open-File Report; Wisconsin Geological and Natural History Survey: Madison, WI, USA, 2003; p. 60.

41. Wisconsin Department of Natural Resources. DNR Groundwater Retrieval Network. Available online: http:/ / prodoasext.dnr.wi.gov/inter1/grn \protect \T1 \textdollar.startup (accessed on 11 May 2016).

42. Mudrey, M.G., Jr.; Bradbury, K.R. Evaluation of NURE Hydrogeochemical Data for Use in Wisconsin Groundwater Studies; Wisconsin Geological \& Natural History Survey Open File Report 93-2; Wisconsin Geological and Natural History Survey: Madison, WI, USA, 1992; p. 61.

43. Smith, S.M. National Geochemical Database: Reformatted Data from the National Uranium Resource Evaluation (NURE) Hydrogeochemical and Stream Sediment Reconnaissance (HSSR) Program: U.S. Geological Survey Open-File Report. 1997; pp. 97-492. Available online: http://pubs.usgs.gov/ of/1997/ofr-97-0492/ (accessed on 13 May 2016).

44. Dickoff, M.E. Modeling Flow and Arsenic Contamination during Aquifer Storage and Recovery Pilot Tests in Green Bay, WI. Master's Thesis, University of Wisconsin, Madison, WI, USA, 2010.

45. Johnson, D.; Wisconsin Department of Natural Resources, Madison, WI, USA. Written communication, 28 August 2008.

46. Hamby, A.; Luczaj, J. Detection and evaluation of an inadvertent cross-connection of a water supply pipeline to a deep well using time-series geochemical and stable isotopic indicators. In Proceedings of the American Water Resources Association, Wisconsin Section Meeting, Wisconsin Dells, WI, USA, 10-11 March 2016.

47. Drever, J.E. The Geochemistry of Natural Waters, 3rd ed.; Prentice Hall: Upper Saddle River, NJ, USA, 1997; p. 436.

48. Wisconsin Department of Natural Resources. Drinking Water Quality Data. Available online: http://dnr.wi. gov/topic/drinkingwater/qualitydata.html (accessed on 10 May 2016).

49. Güler, C.; Thyne, G.D.; McCray, J.E.; Turner, A.K. Evaluation of graphical and multivariate statistical methods for classification of water chemistry data. Hydrogeol. J. 2002, 10, 455-474. [CrossRef]

50. Ponzio, K.; (private mineral dealer). Written communication and samples provided, 14 November 2015.

51. Wisconsin Geological \& Natural History Survey. Minerals of Wisconsin Database. Available online: https://wgnhs.uwex.edu/wisconsin-geology/minerals-wisconsin/ (accessed on 17 March 2016).

52. Heyl, A.V.; Milton, C.; Axelrod, J.M. Nickel minerals from near Linden, Iowa County, Wisconsin. Am. Mineral. 1959, 44, 995-1009.

53. Kerr, P.F. Cattierite and vaesite: New co-ni minerals from the Belgian Congo. Am. Mineral. 1945, 30, $483-497$.

54. Luczaj, J.A.; Millen, T.; Martin, J. A lead-isotopic study of Galena from Eastern Wisconsin: Evidence for lead sources in Precambrian basement rocks. In Proceedings of the Geological Society of America, North-Central/South Central Meeting in Lawrence Kansas, Lawrence, KS, USA, 11-13 April 2007.

55. Luczaj, J.A.; Millen, T.; Martin, J. A lead-isotopic study of galena from Eastern Wisconsin: Evidence for lead sources in Precambrian basement rocks. Econ. Geol. in preparation.

56. Krohelski, J.T. Hydrogeology and Ground-Water Use and Quality, Brown County, Wisconsin; Wisconsin Geological and Natural History Survey: Madison, WI, USA, 1986; Volume 57, pp. 1-42.

57. Luczaj, J.A.; Hart, D.J. Drawdown in the Northeast Groundwater Management Area (Brown, Outagamie, and Calumet Counties, WI), Wisconsin Geological and Natural History Survey-Open File Report, 2009, WOFR2009-04, 60 pages. Available online: http://wgnhs.uwex.edu/pubs/wofr200904/ (accessed on 2 February 2016). 
58. Baeten, J.B. Spatial Distribution and Source Identification of Dissolved Strontium in Eastern Wisconsin's Cambrian-Ordovician Aquifers. Master's Thesis, University of Wisconsin-Green Bay, Green Bay, WI, USA, 2015.

59. Tuttle, M.L.W.; Breit, G.N.; Goldhaber, M.B. Weathering of the New Albany Shale, Kentucky: II. Redistribution of minor and trace elements. Appl. Geochem. 2009, 24, 1565-1578. [CrossRef]

60. CH2M Hill. Green Bay ASR Phase IIA Mineralogical and Water Quality Testing and Results; Technical Memorandum Prepared for Green Bay (Wisconsin) Water Utility August 24, 2000; CH2M Hill: St. Louis, MO, USA, 2000; p. 23.

61. Simo, J.A.; Freiberg, P.G.; Freiberg, K.S. Geologic Constraints on Arsenic in Groundwater with Application to Groundwater Modeling; Groundwater Research Report WRC GRR 96-01; University of Wisconsin Water Resources Center: Madison, WI, USA, 1996.

(C) 2016 by the authors; licensee MDPI, Basel, Switzerland. This article is an open access article distributed under the terms and conditions of the Creative Commons Attribution (CC-BY) license (http://creativecommons.org/licenses/by/4.0/). 